\title{
Reconstruction of Nineteenth-Century Channel Patterns of Polish Carpathians Rivers from the Galicia and Bucovina Map (1861-1864)
}

\author{
Karol Witkowski (D)
}

check for updates

Citation: Witkowski, K.

Reconstruction of

Nineteenth-Century Channel Patterns of Polish Carpathians Rivers from the Galicia and Bucovina Map (1861-1864). Remote Sens. 2021, 13, 5147. https://doi.org/10.3390/ rs13245147

Academic Editors: Maciej Liro, Miloš Rusnák, Monika

Šulc Michalková, Anna Kidová, Zdeněk Máčka, László Bertalan and Malia A. Volke

Received: 16 November 2021 Accepted: 16 December 2021 Published: 18 December 2021

Publisher's Note: MDPI stays neutral with regard to jurisdictional claims in published maps and institutional affiliations.

Copyright: (C) 2021 by the author. Licensee MDPI, Basel, Switzerland. This article is an open access article distributed under the terms and conditions of the Creative Commons Attribution (CC BY) license (https:// creativecommons.org/licenses/by/ $4.0 /)$.
Department of Geoecology and Geoinformation, Institute of Geography, Pedagogical University of Krakow, Podchorążych 2, 30-084 Kraków, Poland; karol.witkowski@up.krakow.pl

\begin{abstract}
Historical maps are often the only source of information allowing for the regional reconstructions of river channel patterns in the past. In the Polish Carpathians, analyses of historical channel patterns were performed mostly in river reaches scale. In this paper, the Galicia and Bucovina map (1861-1864) (the Second military survey of the Habsburg Empire) was used to reconstruct and map the historical channel patterns of seven rivers from the Polish Carpathians. It was found that, in the nineteenth century, rivers in the western part of the study area (Soła, Skawa, Raba, Dunajec) supported a multi-thread channel pattern, whereas rivers in the eastern part (Wisłoka, San, Wisłok) present a mostly single-thread channel pattern. These differences probably result from the higher relief energy and precipitation, lower proportions of forests in the catchments, and more frequent floods favouring high sediment supply to the fluvial system, and thus the formation of multi-thread reaches in the western part of the study area. At the local scale, the most important factor supporting multi-thread channel pattern development was the availability of gravel sediments in the wide valley floor sections. The formation of anabranching reaches with a single mid-channel form was probably associated with the channel avulsion process. There is no clear evidence linking the change in the channel pattern type with an abrupt change in the river channel slope. This study confirms the usefulness of the second military survey map of the Habsburg Empire for the regional reconstruction of river channel pattern types.
\end{abstract}

Keywords: historical maps; channel patterns; rivers classification; anabranching river; morphometric analysis

\section{Introduction}

In river channel research concerning both their historical and contemporary condition, the following parameters are determined: channel pattern, channel width-to-depth ratio, lithology index, and proportion of suspended solids in the transported load [1]. The classifications of channels are based on the analysis of the dominant processes [2,3], channelfloodplain interactions [4], bed material and mobility [5], or channel patterns. According to Meshkova and Carling [6], channel pattern is crucial for the classification of rivers. Rinaldi et al. [7] consider that channel pattern is the most important feature differentiating types of channel, and historical maps or satellite imagery are sufficient to define them. An important problem in the classification of rivers is the subjectivity and ambiguity of the method. Nardini and Brierley [8] solved this problem by providing automatic typology river reaches based on channel patterns through a synthesis of multi-dimensional information. In this method, only the assessment of input criteria based on expert judgment remains subjective. On the other hand, Mandarino et al. [9] propose new GIS tools for active-channel analysis.

Reconstructions of historical channel patterns based on nineteenth-century maps were made for the whole of the Alps [10]. However, such studies were much more common for individual rivers or their reaches [11-15]. A valuable source in research on the 
historical geomorphology of Central Europe is the military surveys map of the Habsburg Empire [16]. Starting with the second edition in the second half of the nineteenth century, these maps accurately reflect the river topography because they were dedicated to military purposes [10].

In the nineteenth century in mountain and upland areas, in Central and Western Europe, multi-thread channel patterns commonly existed in unchannelized rivers. [17,18]. The expansion of the multi-thread channel patterns is usually associated with increased human pressure on forested catchments [19] and increased precipitation during the Little Ice Age [20]. Despite favourable conditions in the catchments, multi-thread channels ceased to exist as a result of numerous hydrotechnical works, which intensified throughout Europe in the twentieth century [12]. Later changes in catchment land use contributed to the consolidation of regulated single-thread channels [21].

Natural factors influencing a channel pattern are divided into those resulting from geology and others [22]. Geology and the resulting orography have the most significant influence on the channels [2]. Other determinants are catchment land use [23] and climate [1]. Werrity and Leys [24] divide river systems into resistant and those sensitive to environmental factors, such as mountain and upland rivers. River metamorphosis leading to a complete change of channel pattern can occur in mountain rivers even due to one extreme flood [25]. Previous studies have presented reconstructions of the nineteenth-century state of several Carpathian rivers: the lower Soła [26], lower Skawa [12], middle and lower Raba [27], upper Dunajec [28,29]. Based on historical Austrian maps, the morphology of Carpathian rivers were also analysed [30-33].

This study reconstructs the channel patterns of the Carpathian tributaries of the Vistula (Soła, Skawa, Raba, Dunajec, Wisłoka, San and its tributary Wisłok), which at the beginning of the twentieth century were subjected to large-scale regulation to prepare the river network for the construction of the Galician Canal [34]. Previous research has focused on the issues of the historical state of individual Carpathian rivers or their reaches, resulting from the unavailability of maps covering the entire research area. This study aims to: (I) provide new insights concerning the possibility of identifying nineteenth-century channel patterns based on historical maps, (II) verify the value of using morphometric analyses in the classification of channel patterns, and (III) discuss the factors determining the formation of specific types of channel pattern.

\section{Research Area}

The research area is located in the Carpathians, in the western part of the Alpide belt [35]. According to the physical and geographic regionalisation of Europe, the Carpathians are in the Province of the Carpathians, Subcarpathians, and Pannonian Plain. The studied rivers drain the mountains of the medium type-Outer Western and Eastern Carpathians and basins - and the Northern and Eastern Subcarpathians (Figure 1). Only the Dunajec River drains the Central Western Carpathians with alpine-type mountains [36].

The rivers, except for the Wisłok (Table 1), are tributaries of the Vistula (Baltic Sea basin) in its upper course. The Wisłok flows into the San and is the only third-order river that, due to its length, is considered one of the main Carpathian rivers.

The main ridge of the Carpathians separates the Baltic Sea catchment to the north from the Black Sea catchment to the east (the Dniester catchment) and to the south (the Danube catchment). The mountain ranges drained by the rivers are mainly made of flysch rocks (except for the Tatra and Pieniny Mountains), which determine the existence of alluvial channels even in their upper reaches. Bedrock channels exist mainly in the source river reaches. The Carpathian rivers had gravel beds. Only in the lower reaches of the San and Wisłoka were there sandy mid-channel forms [37]. The longitudinal extent of the Carpathians north of the European Watershed is up to $100 \mathrm{~km}$. Altitudinal zonation varies from typically mountainous in the south to lowland in the Sandomierz Basin. Annual precipitation totals range from 800 to $1200 \mathrm{~mm}$ and increase from north to south, reaching their highest values in the Tatras (up to $1800 \mathrm{~mm}$ ). In the intramontane 
basins, totals do not exceed $600 \mathrm{~mm}$ and the highest precipitation occurs in the summer months $[38,39]$. The lowest precipitation in the entire Carpathians occurs in the Wisłoka and Wisłok catchments [40].

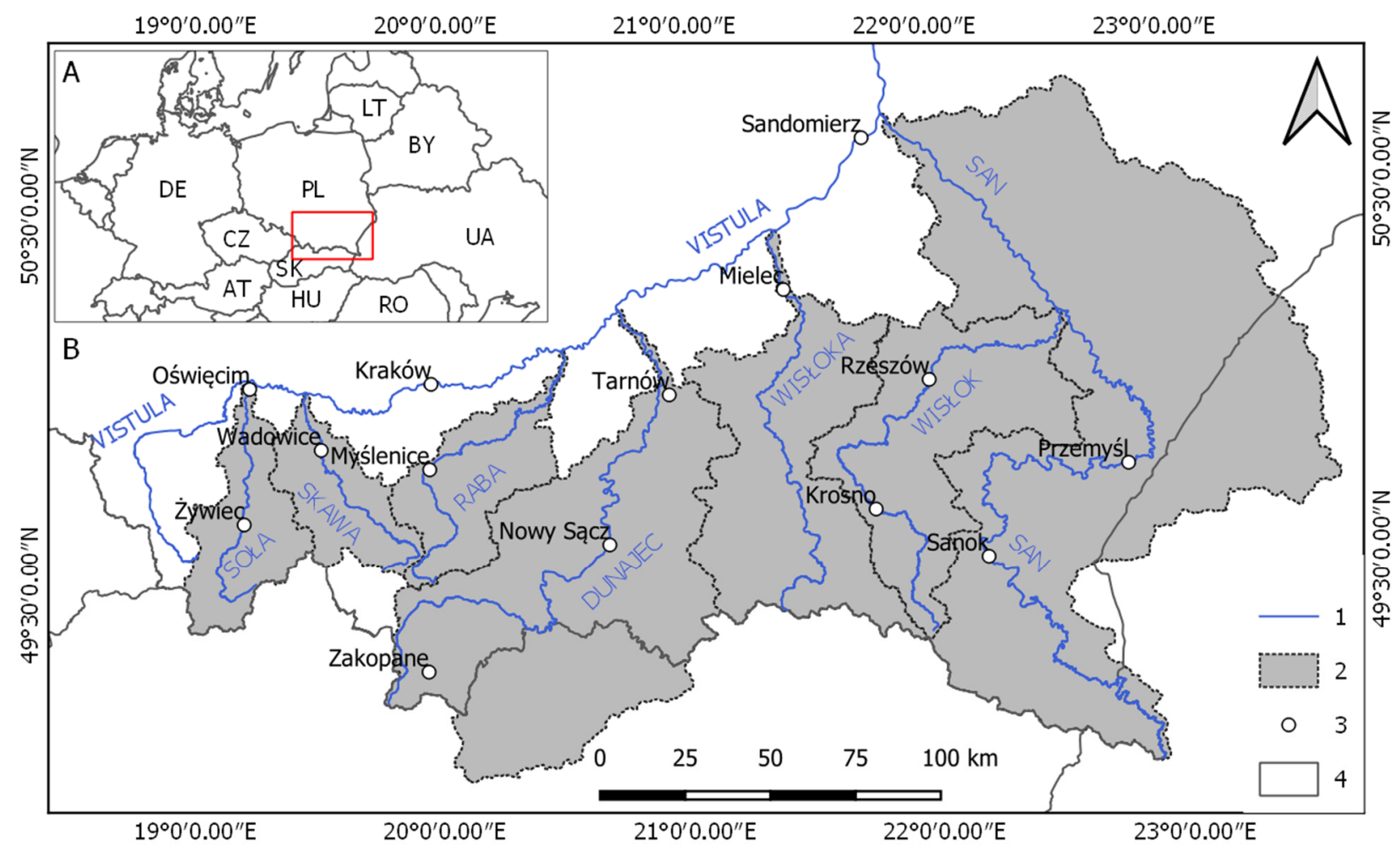

Figure 1. Research area on the map of Europe (A) and in detail (B). Country codes according to the ISO 3166-1 standard. 1-rivers, 2-catchments, 3-main cities, 4-state borders.

Table 1. Basic characteristics of the rivers studied.

\begin{tabular}{|c|c|c|c|c|c|c|}
\hline River & $\begin{array}{l}\text { Length in the } \\
19 \text { th c. }(\mathrm{km})\end{array}$ & $\begin{array}{l}\text { Length of River } \\
\text { Valley }\end{array}$ & $\begin{array}{c}\text { Catchment Area } \\
\qquad\left(\mathrm{km}^{2}\right)\end{array}$ & $\begin{array}{l}\text { Mouth } \\
\text { Elevation } \\
\text { (m asl) }\end{array}$ & $\begin{array}{l}\text { Source } \\
\text { Elevation } \\
\text { (m asl) }\end{array}$ & $\begin{array}{c}\text { Source Reach Name, if } \\
\text { Different from the River } \\
\text { Name }\end{array}$ \\
\hline Soła & 92.3 & 82 & 1390 & 229 & 999 & Bystra ->Ujsoła \\
\hline Skawa & 98.2 & 83.4 & 1166 & 220 & 690 & \\
\hline Raba & 137.5 & 115.9 & 1534 & 180 & 755 & \\
\hline Dunajec & 254.6 & 229.3 & 6767 & 174 & 1500 & $\begin{array}{c}\text { Wyżni Chochołowski -> } \\
\text { Chochołowski -> Czarny } \\
\text { Dunajec }\end{array}$ \\
\hline Wisłoka & 170.6 & 148.5 & 3888 & 156 & 575 & \\
\hline San & 495 & 393.8 & 16,756 & 138 & 920 & \\
\hline Wisłok & 229.3 & 172.8 & 3542 & 168 & 770 & \\
\hline
\end{tabular}

The course of all analysed rivers is divided into mountainous, foothill, and subcarpathian basin. Additionally, there are intramontane basins within four valleys, which constitute separate parts (Figure 1). The longitudinal extent of the valleys increases from west to east, but the most significant factor in this is the increase in extent created by the Sandomierz Basin. This differentiation determines the length variability of both valleys (Table 1) and their parts.

\section{Materials and Methods}

\subsection{Cartographic Sources and GIS Data}

The study of historical channel patterns was based on the Austrian Galicia and Bucovina (1861-1864)—Second military survey of the Habsburg Empire maps, scale 1:28,800. The 
maps were geo-referenced as part of a joint project between the Hungarian Institute and Museum of Military History and Arcanum Ltd. [41]. The maps are available for a fee in WMTS form via the http: / / mapire.eu portal (accessed on 30 September 2021). According to Vichrova [42] the topography and the location of specific points were reproduced on these maps accurately and without distortions. Despite possible positional errors, the presented specific points were considered to be actually existing when the map was drawn [10]. Konias [16] cited the Austrian maps as appropriate sources for researching the geomorphology of rivers in the nineteenth century.

The spatial data illustrating the physical and geographic regionalisation of the Carpathians was obtained from the study by Solon et al. [36]. The .shp files containing the division of Poland into (or as part of) Mesoregions, Macroregions, Subprovinces, Provinces, and Megaregions have been added to the article. This regionalisation is a modification of the division according to Kondracki [43], previously used in Poland.

The data on the geological units over which the rivers flow were obtained from the work of Oszczypko et al. [44]. Although the tectonic sketch map contained in it is very general, it was possible to obtain general information concerning the geological division of the individual catchments. This map was geo-referenced using the location of the main cities in southern Poland and the 16 geological units discussed in the article were then vectorised. In the case of units with a small area, their location was verified using the Detailed Geological Map of Poland, at a scale of 1: 50,000 [45].

In the analysis of valley floor width, the map's relief shading, WMTS [46] was used (accessed on 25 October 2021). The map is available as a free WMTS under its full name The viewing of shaded relief for a digital terrain model with a resolution of $1 \mathrm{~m}$ service (data from the Protection against Natural Phenomena IT System).

Spatial data from the hydrographic division of Poland on the division of the Carpathians into catchments were also used. The data were obtained from a website maintained by the Polish National Water Management Board as part of the National Water and Environmental Program [47]. Data in the .shp format were collected as catchments broken down into surface water bodies. The second-order catchment boundaries were verified according to the position of river mouths in the nineteenth century. Catchment areas beyond the territory of Poland were supplemented with data from the European Environment Agency [48].

\subsection{Typological Analysis of Channel Patterns}

The analytical work began by digitising historical river channels, performed using the QGIS Desktop 3.12.0 with GRASS 7.8.2 program (Open Source Geospatial Foundation, Beaverton, OR, USA). A vector line layer was created for the riverbanks, and a vector polygon layer for the forms for each channel. The active channel was digitised with river banks and bars not covered with vegetation included as part of the channel (Figure 2). The accuracy of the map made it possible to distinguish bars and mid-channel forms not covered with vegetation (mid-channel bars), from those covered with various types of vegetation or with buildings (islands-in the further part of the analysis, inter-channel areas are separated from the islands, Figure 3). A separate polygon was created for each mid-channel form with its surface cover entered in the attributes. 


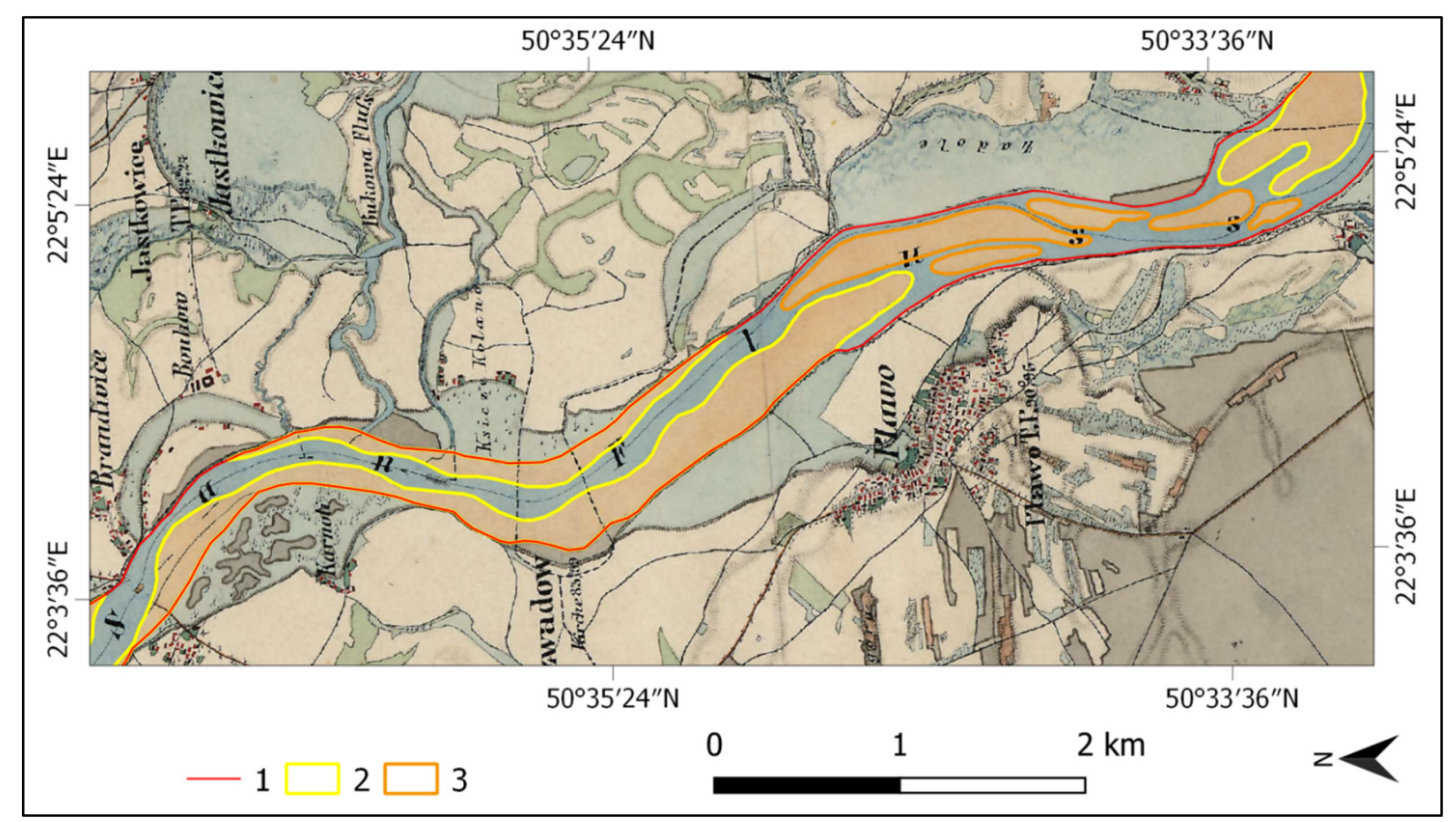

Figure 2. A digitised fragment of the lower San channel. Within the active channel (1), bars (2) and mid-channel bars (3) are marked, and both types of bars not covered with vegetation. Source: Galicia and Bucovina (1861-1864)—Second military survey of the Habsburg Empire, 1:28,800, http:/ / mapire.eu (accessed on 1 October 2021).

Digitization was carried out upstream to source areas, to places where the river course is marked with a single line on the historical map. The source stream of each river was digitised as a single line and joined to the axis of the remaining channel to calculate the tortuosity of the upper course of the river. The channel axis was generated after the linear layer with the river banks was transformed into a polygon layer of active channel. Then a central line was generated as a polygon skeleton. This line was generalised, leaving nodes every $100 \mathrm{~m}$. Straight lines perpendicular to the channel axis, i.e., cross-sections, were created in these nodes. This method allowed for the preparation of a matrix based on which a typology of the channel patterns was made, which assumes, according to the method of Rinaldi et al. [7], that channel forms should be recorded at fixed distances less than the width of the river for most of its course.

In order to analyse the diversity of channel pattern types in the Polish Carpathians in the nineteenth century, Rinaldi et al.'s method [7] was used with additions based on other methods. The classification was based on extended river typology (ERT), taking 22 morphological types of channel into account. The analysis was performed based on channel patterns from the plan, the sinuosity of the channel (SI), braiding index (BI), anabranching index (AI), and many detailed morphologies of the channel that cannot be investigated from maps or satellite imagery. For this reason, the list of possible types was limited to those indicated in Table 2, and only types occurring on gravel beds were analysed. 


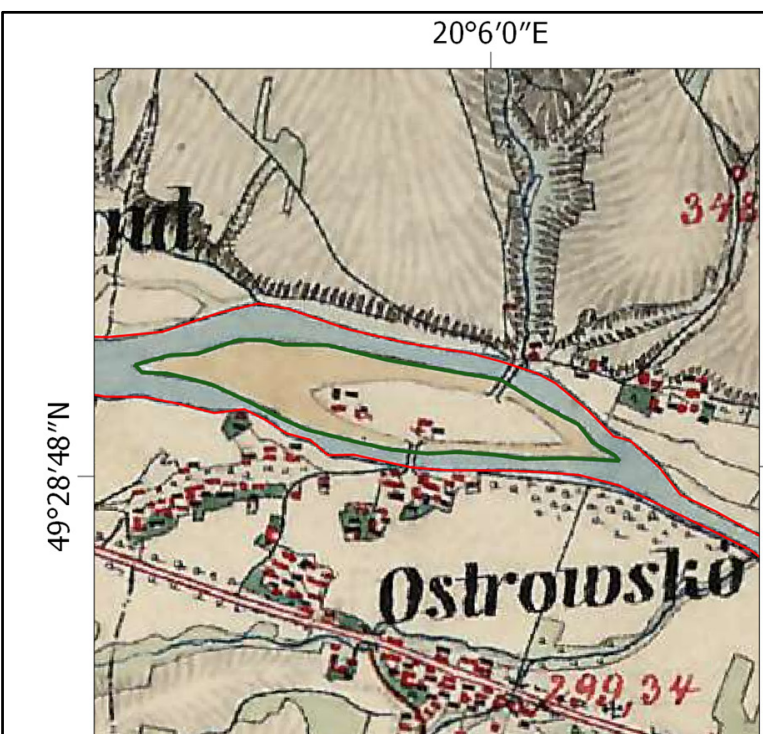

$20^{\circ} 6^{\prime} 0^{\prime \prime} \mathrm{E}$

(a)

$19^{\circ} 58^{\prime} 48^{\prime \prime} \mathrm{E}$

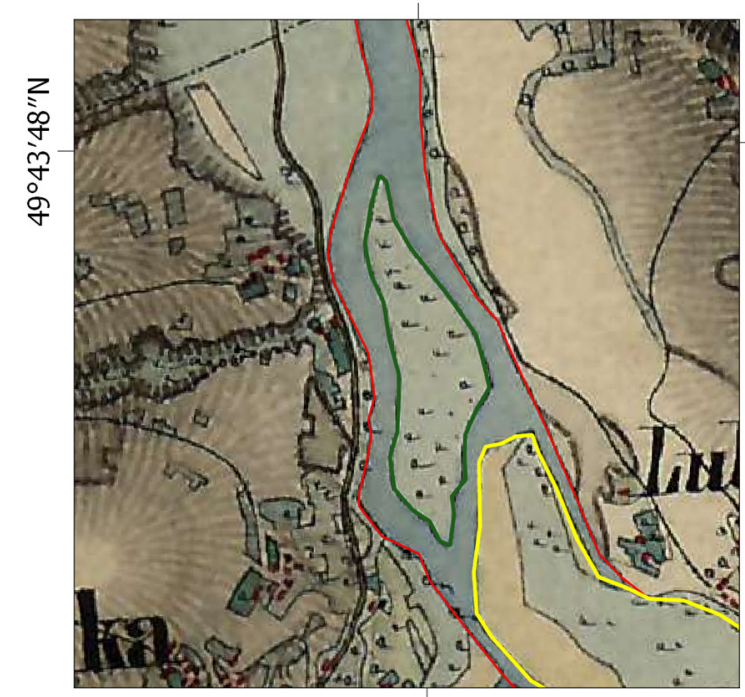

$19^{\circ} 58^{\prime} 48^{\prime \prime} \mathrm{E}$

(c)

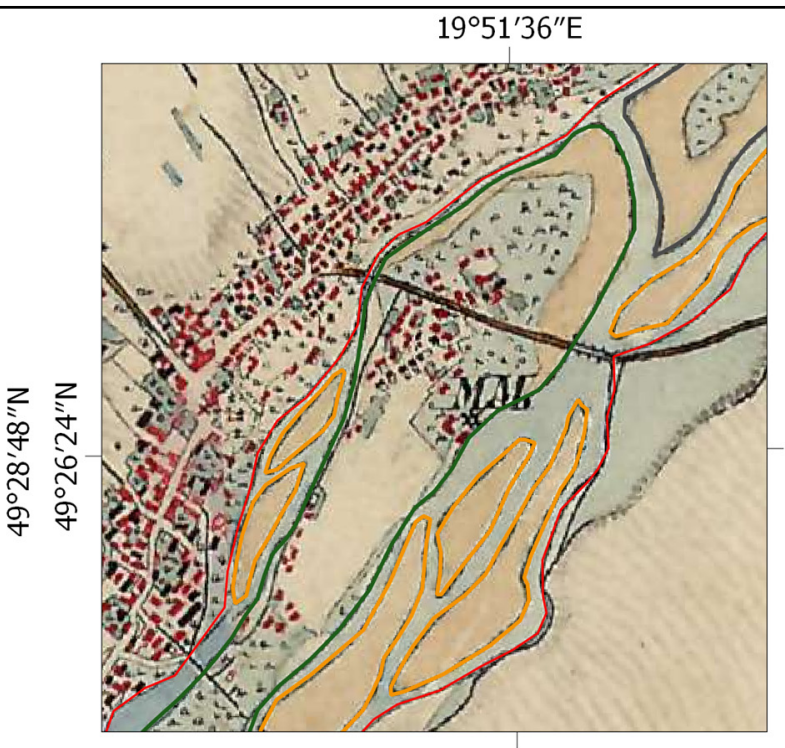

$19^{\circ} 51^{\prime} 36^{\prime \prime} \mathrm{E}$

(b)

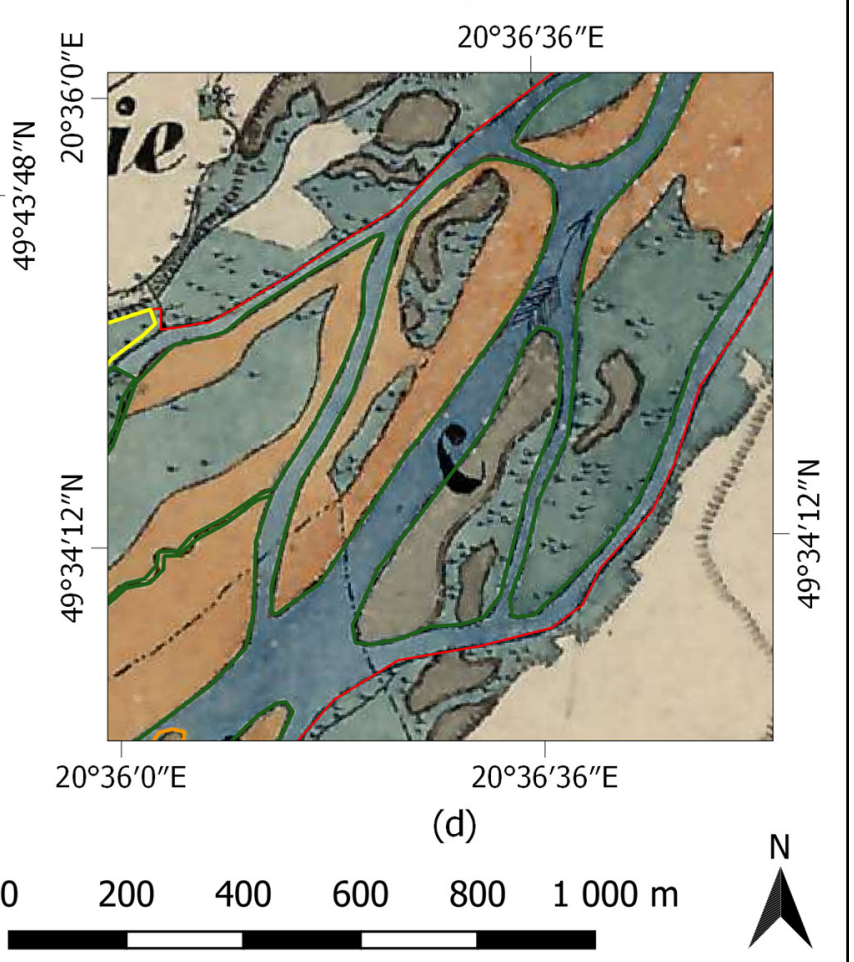

Figure 3. Elements of the relief of the channel and the valley floor digitised as 1—channel banks, 2-bars, 3-mid-channel bars, 4-islands, 5-inter-channel areas; (a) the Dunajec, the village of Ostrowsko-the inter-channel area, built-over in the central part, not covered with vegetation along the banks, connected with the river banks by bridges; (b) the Dunajec, the village of Czarny Dunajec - the inter-channel area, densely built-over in the northern and central part, not overgrown along the banks, connected with the banks by bridges; in the channels located to the east and west of the inter-channel area there are bars not covered with vegetation; (c) the Raba, the village of Pcim—the inter-channel area covered with trees; (d) the Dunajec, the town of Stary Sacz-islands and inter-channel areas partially covered with trees, forest (dark grey filling) or not covered with vegetation. Source: Galicia and Bucovina (1861-1864)—Second military survey of the Habsburg Empire, 1:28,800, http:/ / mapire.eu (accessed on 1 October 2021). 
Table 2. Characteristics of the channel pattern types.

\begin{tabular}{|c|c|c|c|c|c|c|c|c|c|}
\hline & & \multirow{2}{*}{$\begin{array}{c}\text { Basic } \\
\text { Classification } \\
\text { Rinaldi et al. } \\
\text { [7] }\end{array}$} & \multicolumn{2}{|c|}{ Additions to the Classification } & \multirow{2}{*}{$\begin{array}{l}\text { Designation } \\
\text { in the Study }\end{array}$} & \multirow{2}{*}{$\begin{array}{l}\text { Mid-Channel } \\
\text { Forms }\end{array}$} & \multirow{2}{*}{ BI } & \multirow{2}{*}{ AI } & \multirow{2}{*}{ SI } \\
\hline & & & $\begin{array}{c}\text { Brice \& Blodgett } \\
{[49]}\end{array}$ & Teisseyre [50] & & & & & \\
\hline \multirow{9}{*}{ 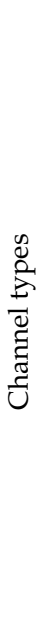 } & \multirow{5}{*}{ 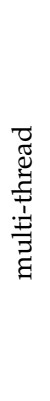 } & \multirow[t]{2}{*}{$\begin{array}{l}\text { anabranching } \\
\text { (high energy) }\end{array}$} & $\begin{array}{l}\text { anabranching with } \\
\text { channels of low } \\
\text { sinuosity }\end{array}$ & $\begin{array}{l}\text { adaptation of the } \\
\text { length and width of }\end{array}$ & $\mathrm{A}$ & inter-channel areas & 1 & $>1.5$ & - \\
\hline & & & $\begin{array}{l}\text { anabranching with } \\
\text { complex channels }\end{array}$ & $\begin{array}{l}\text { the inter-channel } \\
\text { areas to gravel-bed } \\
\text { rivers }\end{array}$ & $\mathrm{AB}$ & $\begin{array}{l}\text { inter-channel areas, } \\
\text { islands, } \\
\text { mid-channel bars }\end{array}$ & $>1$ & $>1.5$ & \\
\hline & & \multirow{2}{*}{$\begin{array}{l}\text { braiding } \\
\text { braiding with } \\
\text { islands }\end{array}$} & & & B & \multirow{2}{*}{$\begin{array}{l}\text { mid-channel bars } \\
\text { islands, } \\
\text { mid-channel bars }\end{array}$} & $>1.5$ & 1 & \multirow[t]{2}{*}{ - } \\
\hline & & & & & IB & & $>1.5$ & $>1$ & \\
\hline & & wandering & & & W & $\begin{array}{c}\text { islands, } \\
\text { mid-channel bars }\end{array}$ & $<1.5$ & $<1.5$ & - \\
\hline & \multirow{4}{*}{ 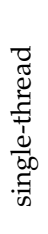 } & sinuous & \multirow{4}{*}{$\begin{array}{l}\text { delimitation of } \\
\text { single-thread } \\
\text { channels with } \\
\text { single mid-channel } \\
\text { forms }\end{array}$} & & $\mathrm{S}$ & \multirow{4}{*}{$\begin{array}{c}\text { islands, } \\
\text { mid-channel bars }\end{array}$} & - & _- & $>105<15$ \\
\hline & & & & & SB & & - & - & $>1.05 \leq 1.5$ \\
\hline & & meandering & & & $\begin{array}{c}\mathrm{M} \\
\mathrm{MB}\end{array}$ & & - & - & $>1.5$ \\
\hline & & straight & & & $\begin{array}{c}\mathrm{T} \\
\mathrm{TB}\end{array}$ & & - & - & $\leq 1.05$ \\
\hline
\end{tabular}

The Brice \& Blodgett method [49] allows for a division similar to that obtained by Rinaldi et al. [7] however, it contains additional divisions into degrees of sinuosity, braiding and anastomosing which have no hydraulic justification. The authors, however, proposed that single-thread channels with individual mid-channel bars or islands should be distinguished from single-thread channels (Table 2). This seems particularly important when analysing rivers or their reaches where there is a tendency to braid. Moreover, in this method, it has been proposed to distinguish within anabranching-type channels those that have side braiding.

The BI (braiding index) and/or AI (anabranching index), i.e., the number of currents flowing around the mid-channel form, were calculated for each cross-section. In the case of channels without mid-channel forms, BI and AI were 1 . The AI was calculated only for those cross-sections with preserved forms, i.e., overgrown and/or built-over to at least $50 \%$. In addition, these forms had to meet the morphometric requirements for inter-channel areas according to the Brice and Blodgett method [49]. Using this method, the length and width ( $L$ and $\left.w^{\prime}\right)$ of each island with at least $50 \%$ cover were measured. Additionally, the width of the currents flowing around the form was measured $(w)$. A modification of the Brice and Blodgett [49] method developed by Teisseyre [50], who adapted it to gravel-bed rivers, was used to analyse the results. According to this method, the mid-channel form can be classified as an inter-channel area if it meets the following condition:

$$
\frac{L}{w} \geq 4 \vee \frac{w^{\prime}}{w} \geq 1
$$

Based on the morphometric analysis according to Brice and Blodgett [49], the following mid-channel forms were distinguished (Figure 3):

- Mid-channel bars: Bars not covered with vegetation

- Islands: Forms wholly or partially covered with vegetation, but not meeting the condition of Formula (1)

- Inter-channel area: Forms covered in at least $50 \%$ by vegetation or buildings and meeting the condition of Formula (1)

Delimiting inter-channel areas is especially important from the hydraulic point of view. These areas are not channel forms, but valley floor forms, so during floods, they 
undergo the same processes as floodplains. These areas are permanent forms that stabilise the river reaches.

The procedure for delimiting typological sections started with selecting multi-thread reaches. First, those with inter-channel areas were indicated. Then, two reaches with interchannel areas were joined together if the averaged AI index, calculated for the cross-sections (cs) and a separating section of another type, did not reach a value below 1.5:

$$
A I=\frac{c s_{1}+c s_{2}+c s_{3}+\ldots+c s_{n}}{n} \geq 1.5
$$

In this way, type A anabranching reaches were delimited. If there were islands or mid-channel bars within channels surrounding the inter-channel areas, that is:

$$
B I=\frac{c s_{1}+c s_{2}+c s_{3}+\ldots+c s_{n}}{n}>1
$$

anabranching reaches with braided channels were delimited-AB. Then, sections were indicated in which there were inter-channel areas, islands, and mid-channel bars in the immediate vicinity, i.e., wandering reaches-W:

$$
B I=\frac{c s_{1}+c s_{2}+c s_{3}+\ldots+c s_{n}}{n}<1.5 \wedge A I=\frac{c s_{1}+c s_{2}+c s_{3}+\ldots+c s_{n}}{n}<1.5
$$

Next, reaches were indicated with at least one transverse profile showing $B I \geq 3$. To such reaches, adjacent ones with at least one mid-channel bar or island were connected if the entire section maintained a $B I$ index $\geq 1.5$ :

$$
B I=\frac{c s_{1}+c s_{2}+c s_{3}+\ldots+c s_{n}}{n} \geq 1.5
$$

In this way, the braided B reaches were delimited if all mid-channel forms were bars not covered with vegetation, or BI reaches if islands were among the mid-channel forms. The remaining reaches where $\mathrm{BI}=1$ and $\mathrm{AI}=1$ were treated as single-thread.

The division into straight $(\mathrm{T})$, sinuous $(\mathrm{S})$, and meandering $(\underline{\mathrm{M}})$ reaches was based on the SI (sinuosity index, Table 2):

$$
S I=\frac{\text { length of the channel axis }}{\text { length of the valley floor axis }}
$$

The valley floor extent was determined using the relief shading map. In the mountain and foothill regions, the floor of the valley reached the junction of the flattened area and the base of the slope, while in the basins it reached the farthest paleo-meanders visible in the relief. Single mid-channel forms were treated as elements of a single-thread channel with branches (TB, SB, MB).

\section{Results}

\subsection{Historical Channel Patterns of Carpathian Rivers}

In the nineteenth century, the channel patterns of the Carpathian rivers differed between the studied rivers and along their courses. As shown in Figure 4, the river channel patterns in the western part of the Carpathians are more diverse (Soła-Dunajec) than in the eastern part (Wisłoka-San). 


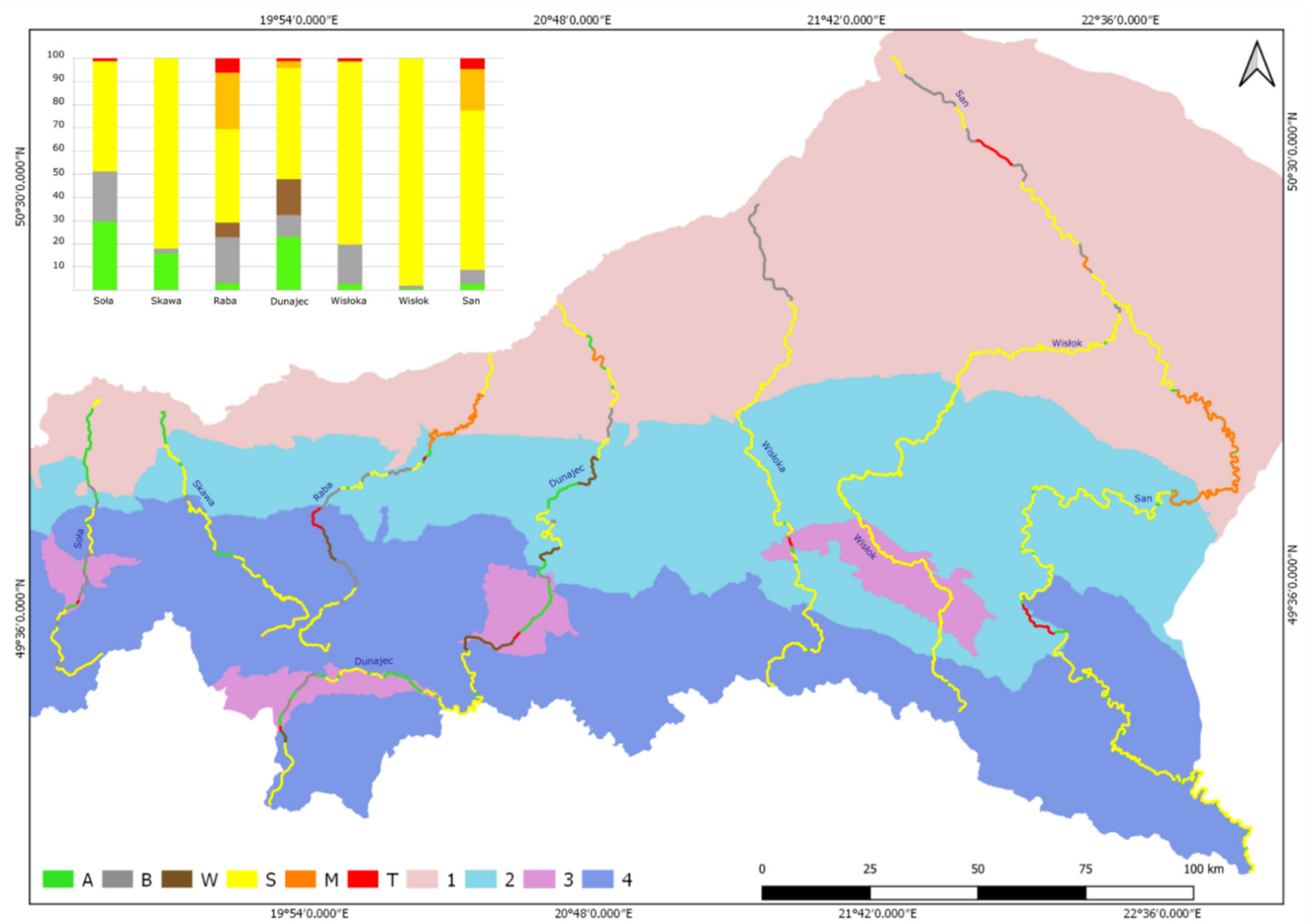

Figure 4. Division of the channel reaches of the studied rivers into anabranching (A), braiding (B), wandering (W), as well as sinuous (S), meandering (M) and straight (T) channel patterns. The graph shows the contribution of the types of channel patterns to the length of the river. In order to visualise the results of the classification, the drawing for each river was generalised by creating a 300-m buffer from its axis. 1-subcarpathian basins, 2-foothills, 3-intramontane basins, 4-mountains.

\subsubsection{The Mountain Courses of the Studied Rivers}

Single- and multi-thread reaches have been identified in all the mountain river valleys in the Western Carpathians. The common feature of the mountain courses of all rivers was the presence of short reaches of the anabranching type. Only in the Soła channel did an anabranching reach not exist, but there were two braiding sections near the mouths of the Soła tributaries. On the other hand, in the Skawa channel, there was a long anabranching reach (4.7 km long, Figure A1 and Table A1 (A201) in Appendix A). In the Raba channel, a long multi-thread reach $(17.7 \mathrm{~km})$ was identified (IB301-B303). The availability of sediment was due to the supply from Raba's mountain tributaries. The mountain part of the Dunajec is the least diversified of all parts of its valley. The source is located in the Tatra Mountains and is separated from its route through the Pieniny and Beskidy Mountains' gorge by a basin.

The mountain courses of the rivers in the eastern part of the study area are characterised by the presence of long single-thread reaches with short anabranching sections separating them. In the San channel, all anabranching reaches are located in one interchannel area in the mountain part of the valley. These do not exceed $1 \mathrm{~km}$ in length.

\subsubsection{The Intramontane Basins Courses of the Studied Rivers}

The Soła and Dunajec channels in the intramontane basins were mainly multi-thread. In the Żywiec Basin, three multi-thread reaches had a total length of $15.9 \mathrm{~km}$. Mid-channel 
forms preserved by vegetation dominated (AB103) in the higher, southern part of the basin. On the other hand, in the central and northern parts, mid-channel bars (IB104, IB103) dominated. The forms preserved by vegetation were mainly forested. In the Orawa-Nowy Targ Basin, as in the Żywiec Basin, multi-thread reaches dominated. The largest interchannel area was within the village of Czarny Dunajec with an area of nearly $0.39 \mathrm{~km}^{2}$ and $2.1 \mathrm{~km}$ long. There were buildings and bridges on it. Upstream there was an inter-channel area in Koniówka of $0.38 \mathrm{~km}^{2}$ and $1.3 \mathrm{~km}$ long, connected to the left bank with bridges. This area was probably used for agriculture. In the northern part of the basin, there was a built-over area belonging to the village of Maniowy $\left(0.32 \mathrm{~km}^{2}\right.$ and $1.2 \mathrm{~km}$ long).

The most substantial diversity of channel patterns was recorded in the Sacz Basin. Of the four reaches, only one was single-thread (T401), while the four others were W403, AB403, AB402 and B401. All the islands and inter-channel areas were partially or entirely covered with forest. None was built over.

The Jasło-Krosno Basin was the only basin within the valleys in the eastern part of the study area. Two rivers flow through it, namely the Wisłok and Wisłoka. The Wisłok river channel in the Jasło-Krosno Basin is $54.7 \mathrm{~km}$ long, but it is one reach of the SB type (SB703). The Wisłoka basin reach is much more varied. It consists of three A (A501-A503) and AB501 multi-thread reaches (total length $3 \mathrm{~km}$ ). The largest inter-channel area is $0.09 \mathrm{~km}^{2}$.

\subsubsection{The Foothill Courses of the Studied Rivers}

In all the analysed rivers, at least one reach A was identified in the foothill courses. In the case of the Soła and Skawa, these courses had one each a long anabranching reach.

The foothill courses of the Raba and Dunajec channels were much more diverse in term of channel patterns types. There were six multi-thread reaches within the $41.8 \mathrm{~km}$ of the middle part of the Raba. Type B reaches dominated. In the foothill part of the Dunajec channel, there were two $W$ reaches (W402, W401)) with a total length of $19.1 \mathrm{~km}$, a short $1.5 \mathrm{~km} \mathrm{IB402}$, and two $A B$ sections with lengths of $3.8 \mathrm{~km}(\mathrm{AB} 402)$ and $10.5 \mathrm{~km}$ (AB401). $\mathrm{AB} 401$ was the longest anabranching reach in the foothill courses of all rivers studied.

The foothill courses of the Wisłoka and Wisłok were of the sinuous type with single and short anabranching reaches.

Single-thread reaches with a total length of $139.1 \mathrm{~km}$ dominated the foothill part of the San. These included a long MB section (MB602-11.6 km) and a T connecting the anabranching reaches $(\mathrm{T} 602-12.1 \mathrm{~km}$, the most extended straight section identified in the entire study area). The total length of six anabranching reaches was $4.3 \mathrm{~km}$.

\subsubsection{The Subcarpathian Basins Courses of the Studied Rivers}

Among the subcarpathian basin courses, the Skawa and Sola rivers with an anabranching channel pattern dominate. In the Soła channel, the most extended reach of the AB type was $20.6 \mathrm{~km}$ (AB101). The largest inter-channel area was $0.81 \mathrm{~km}^{2}$ and $2.5 \mathrm{~km}$ long. All areas were partially or entirely forested, but none of them was built over. In the Skawa channel, the type $\mathrm{AB}$ mouth reach was $8.8 \mathrm{~km}$ long (AB201). The largest was $0.46 \mathrm{~km}^{2}$ and $1.8 \mathrm{~km}$ long and was partially built-over. The Skawa was the only river analysed to have an anabranching lowermost reach.

The Raba in its subcarpathian basin part had the least diversified channel among the rivers studied. An MB reach (MB301) preceded a lowermost section of the SB type.

The Dunajec subcarpathian basin part began with a $7.6 \mathrm{~km}$ long IB channel (IB401). Downstream it was a long single-thread channel $(29.2 \mathrm{~km}$ in total) separated by three $\mathrm{A}$ reaches. The last reach of the $\mathrm{AB}$ type in the Dunajec channel was an anthropogenic anastomosis with two inter-channel areas (A401). The larger of them had the greatest area of all the inter-channel areas identified in the study area at $1.1 \mathrm{~km}^{2}$ (with a length of $1.7 \mathrm{~km})$.

The subcarpathian basin course of the Wisłok and Wisłoka were similar, and both rivers developed braided reaches at their lowermost course. The Wisłoka had a long IB 
type lowermost reach (IB501-29.1 km). The Wisłok, on the other hand, had less than $3 \mathrm{~km}$ of a B-type lowermost reach (B701).

The subcarpathian basin part of the San was the most diverse and longest among the rivers studied $(200.1 \mathrm{~km})$. Single-thread reaches were $168 \mathrm{~km}$ long, meandering $76.7 \mathrm{~km}$, and straight $10.7 \mathrm{~km}$ (T601). The longest of the braided reaches was $15.5 \mathrm{~km}$ (B601).

\subsubsection{Common Features of Channel Pattern Types}

Among 30 A-type reaches, as many as 26 had only one inter-channel area. The width of the reaches with one inter-channel area was between 47 and $418 \mathrm{~m}$ and lengths were from 177 to $1312 \mathrm{~m}$. As many as 17 of them were in valleys with an average width of less than $1 \mathrm{~km}$. Moreover, $96.7 \%$ of A-type reaches were preceded and followed by single-thread sections. A further $36.7 \%$ of $A$ reaches were preceded by $S$ sections, while in the case of $A B$ reaches, it was only $9.1 \%$ (Table A2).

The A-type were most often found in the mountains (40\%) as short reaches with one inter-channel area. Further, 33\% of A-type were identified in the foothill courses and the smallest number were found in basins. This distribution should be related to the nature of the reaches, where those with one inter-channel area were dominant. Therefore, their formation should be associated with very local conditions, e.g., with individual obstacles on the riverbed initiating the formation of an A-type reach by avulsion rather than aggradation.

The $A B$ reaches were from 323 to $20,569 \mathrm{~m}$ long and 99 to $871 \mathrm{~m}$ wide. The $A B$ reaches were dominated by long and wide sections, in contrast to A (Figure 5). AI was in the range (1.52-2.54), with as many as $36 \%$ equal to or exceeding a value of 2 . Ten $A B$ reaches had only one inter-channel area. These sections did not exceed $2.4 \mathrm{~km}$ in length, and as many as eight of them were found in the mountain or foothill courses. The three most extended $A B$ reaches were over $11 \mathrm{~km}$ long (AB403, AB405, AB101). In general, AB type reaches were most often identified in the intramontane basins, namely $41 \%$, and in the foothills, $27 \%$.

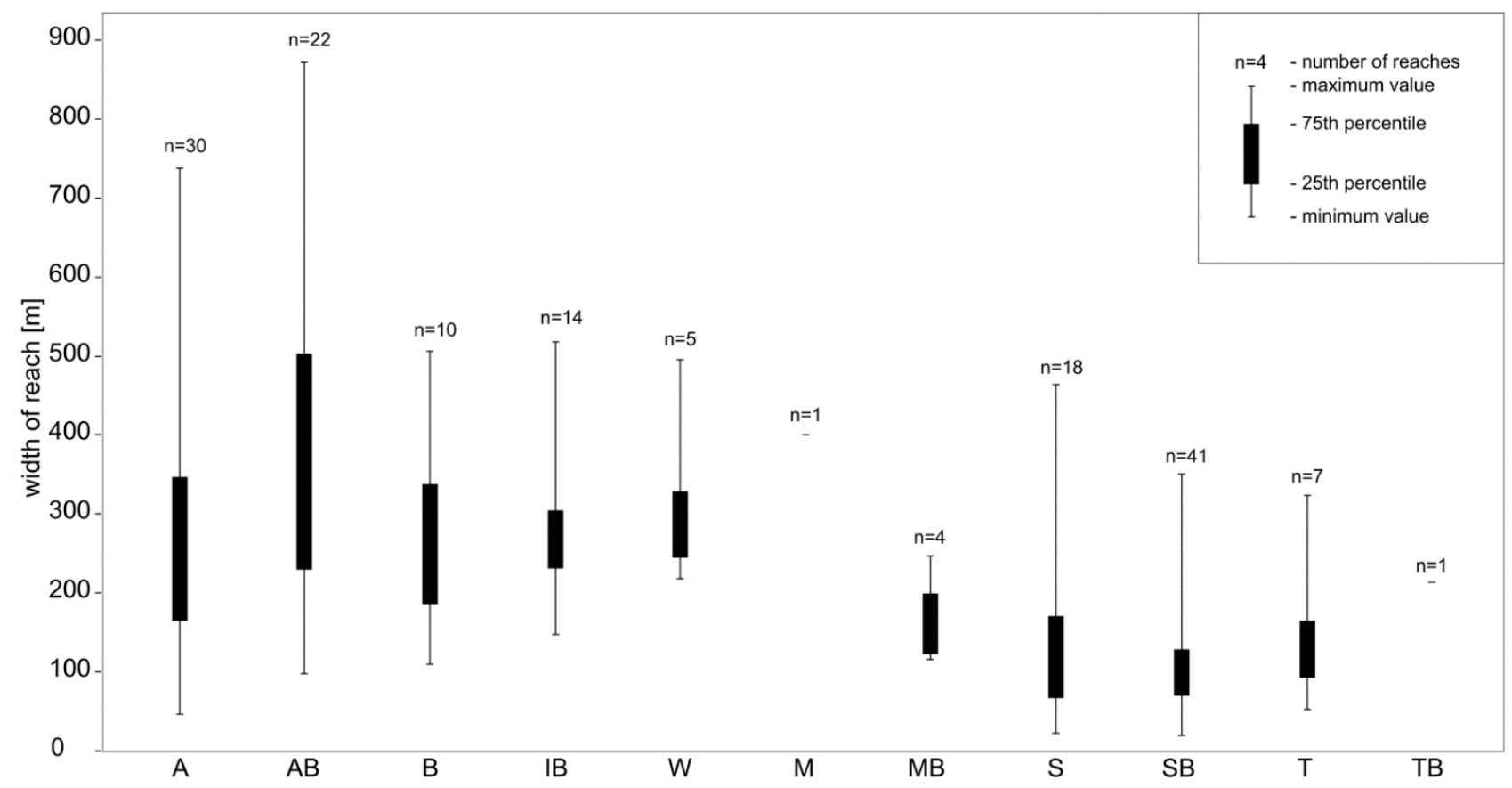

Figure 5. The range of widths of studied reaches according to their channel pattern types: A-anabranching, ABanabranching with braided channels, B-braiding, IB — braiding with islands, W—wandering, M-meandering, MBmeandering with mid-channel forms, S—sinuous, SB—sinuous with mid-channel forms, T—straight, TB—straight with mid-channel forms. 
Braided reaches preceded the AB-type in $22.7 \%$ of occurrences, and in $27.2 \%$ they were followed by braided or wandering sections (Table A3). This indicates that the braided nature of the channels flowing through the inter-channel areas in AB-type reaches was usually associated with the local anabranching system and not with the general tendency to braid along the river course. This is also confirmed by the small proportion of anabranching reaches in the vicinity of B-type sections (10\% of the preceding and $10 \%$ following).

The analysis of the slope of $\mathrm{AB}$ and preceding reaches shows no clear premise for linking the change in the type of channel pattern with a sudden change in the river channel slope. Hence, $59 \%$ of the $\mathrm{AB}$ reaches developed in basins favoured by the availability of sediment covering the floor and its width. Additionally, in four cases, these reaches functioned just below tributaries of a mountain stream character. In the case of three out of six $\mathrm{AB}$ reaches in the foothills, a sudden increase in the supply of gravel by tributaries should be indicated as the direct cause likewise, for the three sections identified in the mountains, where two developed downstream of tributaries. In the case of two reaches, $\mathrm{AB}$ in the foothills and one in the mountains, it is not easy to indicate the direct cause of the development of the channel pattern. As in most A reaches, it should be associated with very local conditions and avulsion as an initiating process.

Most of the braided reaches were 1198-9073 m long and the most extended B section was $15,517 \mathrm{~m}$ long, and IB 29,052 $\mathrm{m}$ (Figure 5). All braided reaches were 110-519 m wide. The IB coefficient in the braided channels reached 2.6, while the AI in the IB channels reached 1.19.

Braided reaches were most often recorded in the subcarpathian basins. In the case of rivers in the eastern part of the studied area, braided channels were identified only in the subcarpathian basins. The presence of braided reaches in the mouth of the Wisłoka and Wisłok should be explained by the deposition triggered by a small drop in the valley floor (below 1\%o), controlled by the larger river. In the case of the San, braided reaches were located in the vicinity of sinuous or meandering channels with a high SI. For rivers in the western part of the area, braided reaches were found in all courses, but in the intramontane basins they were always located within anabranching reaches.

W-type reaches were $3363-16,860 \mathrm{~m}$ long and $218 \mathrm{~m}$ to $497 \mathrm{~m}$ wide (BI: $1.22-1.43$, AI: 1.1-1.49). All identified reaches of the wandering type were located in the Dunajec and Raba channels, and in all parts of the valleys, except for the subcarpathian basins. In three cases, $\mathrm{W}$ reaches were preceded by multi-thread channels and in two cases by SB sections, but single-thread channels always followed them.

The SB reaches have the greatest length range from $1453 \mathrm{~m}$ to $127149 \mathrm{~m}$ (Figure 5). Single-thread channel widths ranged from 20 to $464 \mathrm{~m}$. The greatest dispersion of values was recorded in the SB channel type. The meandering reaches had a SI coefficient of 1.54-1.93 and were always located in the lowest basin courses of the Carpathian rivers, although one of the MB types started in the foothills (Table A2). However, the only TB reach was recorded on a mountain course. Sinuous reaches were most often recorded in the mountains (S-44\%, SB-46\%) and $57 \%$ of $\mathrm{T}$ sections were located in intramontane basins, separated by multi-thread reaches.

Single-thread always functioned directly adjacent to multi-thread reaches (Table A3). The exception was the SB type, where $2.5 \%$ (just one) was preceded by an MB reach.

\subsection{Orographic and Geological Conditions Controlling the Type of Channel Pattern}

The mountain courses of the Soła, Skawa, Raba, Dunajec, and Wisłoka valleys are of similar lengths ranging from 40.1 to $63.0 \mathrm{~km}$ (Figure 6). However, these rivers vary in terms of the proportion of the mountain part in the length of the entire valley. The mountain part of the Skawa constitutes $75.5 \%$ of the valley length, but the Dunajec only $24.5 \%$. The San has the most extended mountain part at $138.1 \mathrm{~km}$, while the shortest is the Wisłok at $26.5 \mathrm{~km}$. All the mountain reaches have deep valleys with narrow floors. This causes a significant limitation to the possibility of channel migration and favours the formation of sinuous channels with a significant drop in elevation. Analysis shows that the actual 
length of mountain valleys increases from west to east. This confirms the dependence of the length of the mountain part on the longitudinal extent of the mountain area. The proportion of the mountain part in the length of the entire river decreases from west to east, which reflects the increase in the longitudinal extent of the subcarpathian basins towards the east.
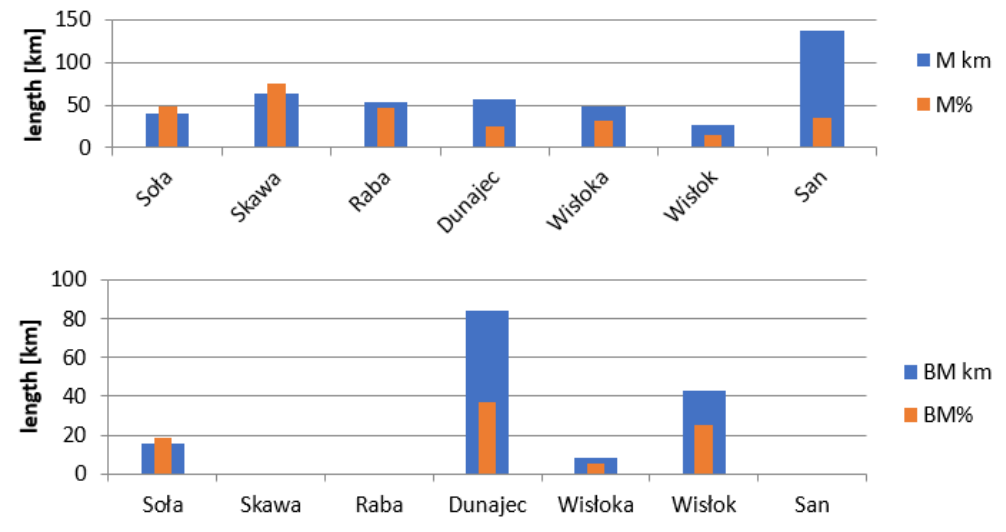

$\mathrm{BM} \%$
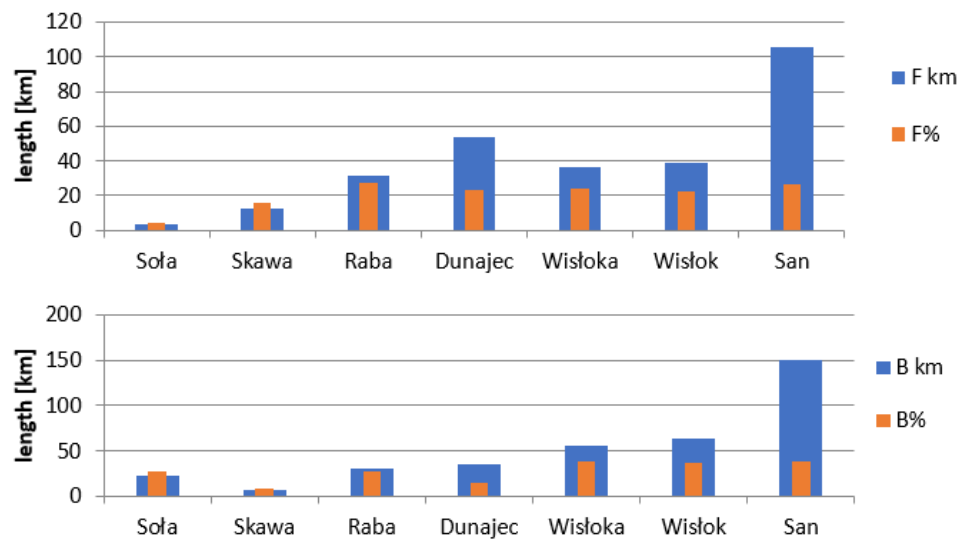

Figure 6. The length of the delimited courses of the main Carpathian river valleys and their proportion in the length of their entire courses divided into mountainous (M), intramontane basin (BM), foothill (F) and subcarpathian basin (B) courses.

From the point of view of geological structure and orography, the mountain courses should be analysed according to a division into the rivers of the Western Beskidy and Central Western Carpathians (from the Sola to Dunajec) and the rivers of the Mid Beskidy and Lesiste Beskidy (from the Wisłoka to San). The Western Beskidy show a distinct duality and its higher parts are the Żywiec-Kysuce Beskid, Żywiec-Orawa Beskid, Gorce, and Sacz Beskid. In these mountain groups, the highest source reaches of the valleys of the Soła, Skawa and Raba, and the Dunajec are located, flowing into their area after leaving the Orawa-Nowy Targ Basin. Together with the Tatra Range, where the source reach of the Dunajec is located, these mountain groups have the highest relief energy in the Polish Carpathians. This is confirmed, for example, by the steepness of the valley floor slope in the highest reaches of the Soła (3.8\%) and Dunajec (4.1\%) channels. Moreover, the massifs of the Western Beskidy are primarily composed of the Magura Nappe and Silesian Nappe flysch sediments (Figure A2). The Wisłok has the shortest mountain part among the rivers, which in its source area drains the eastern part of the Low Beskidy, a visible lowering of the Carpathian range, and the border of the Western and Eastern Carpathians. For this reason, the entire mountain part of the floor of the Wisłok valley has a drop in elevation of $2.8 \%$, one of the highest values in the entire study area (Table 3 ). 
Table 3. Slopes (\%o) of the valley floors of the main Carpathian rivers divided into mountain (M), intramontane basins (BM), foothills (F) and subcarpathian basins (B).

\begin{tabular}{ccccc}
\hline River & M & BM & F & B \\
\hline Soła & $21^{*}$ & 4.51 & 3.6 & 2.4 \\
\hline Skawa & $2.85^{* *}$ & & 2.53 & 2.03 \\
\hline Raba & 6.7 & & 2.51 & 0.84 \\
\hline Dunajec & 8.81 & $35.8^{\prime \prime}$ & $5.91 \sim$ & \\
& $3.27^{\prime \prime}$ & $2.84 \sim \sim$ & 0.51 \\
\hline Wisłoka & 7 & 2.4 & 1.09 & 0.69 \\
\hline Wisłok & 27.9 & 3.44 & 3.23 & 0.72 \\
\hline San & 4.43 & & 1.01 & 0.41
\end{tabular}

* upstream from Żywiec Basin; ** downstream from Żywiec Basin;' upstream from Orawa-Nowy Targ Basin; ${ }^{\prime \prime}$ downstream from Orawa-Nowy Targ Basin; Orawa-Nowy Targ Basin; Sacz Basin.

The intramontane basins do not show any relation with the variability of the length of the main Carpathian rivers from west to east. The two basins drained by the Dunajec, the Orawa-Nowy Targ and Sacz Basins make up the largest proportion in the length of the entire valley $(36.7 \%)$. On the other hand, $25 \%$ of the length of the Wisłok valley is located in the Jasło-Krosno Basin while a part of the Wisłoka valley is also located in this valley $(5.5 \%$ of its course). Moreover, $18.7 \%$ of the length of the Soła valley is located in the Żywiec Basin. Within intramontane basins, a sudden expansion of the valley floor area allows for the formation of many channels, usually of the multi-thread type. Braided patterns developed more frequently in basins where the valley floors have steeper slopes (Żywiec and OrawaNowy Targ Basins, Table 3). On the other hand, in basins with gentler longitudinal slopes (the Wisłoka valley in the Sacz and Jasło-Krosno Basins), mid-channel forms consolidated with vegetation developed more often. The exception is the Jasło-Krosno Basin in the Wisłoka Valley where, due to a higher drop (3.44\%) and a lower supply of sediment from the short mountain valley, a single-thread reach has developed.

The Żywiec Basin is located within the Magura Nappe that itself overhangs the Silesian Nappe. However, its flattening is determined by the presence of a tectonic window uncovering Sub-Silesian Nappe deposits. In the Sacz Basin tectonic depression, Miocene sediments are exposed within the Magura Nappe. In the case of the Orawa-Nowy Targ Basin, the Miocene deposits are exposed on the border between the Magura Nappe and the Inner Carpathian Paleogene Basin. Only in the Jasło-Krosno Basin, has the lowering developed within a single geological unit-the Silesian Nappe. The thickness of the valley floor deposits depends on the size of the supply area. Therefore, multi-thread gravel beds have developed in the basin reaches of the Soła, Dunajec, and Wisłoka.

The long reach of the anabranching type in the mountain course of the Skawa confirms the existence of a small intramontane basin which, according to physical and geographic regionalisation, has not been delimited as a separate unit. At this point, the floor of the valley has an average width of $535 \mathrm{~m}$ and a longitudinal slope of $4.99 \%$, close to the values for the large intramontane Żywiec and Orawa-Nowy Targ Basins. In this case, inter-channel areas developed due to the aggradation of coarse-grained and organic material, which enabled forest development and their preservation.

Among the foothill parts of the valleys, are the Raba, Wisłoka and Wisłok, which are 31.9-39.1 km long. Only the Dunajec, with $53.7 \mathrm{~km}$, and the San, $105.8 \mathrm{~km}$, have more extended foothill valleys. The Soła and Skawa valleys have much shorter foothill parts and the lowest values $(4.4 \%$ and $15.6 \%$ ) in proportion of the length of their entire valleys. The proportions of the remaining rivers are in the range of $22.6-27.5 \%$. The length of the foothill courses is inversely proportional to the drop in elevation of the valley floors which 
decreases from west to east. The only exception is the Wisłok valley where the higher drop $(3.23 \%$ ) results from neotectonic movements.

The Western Beskidy Foothills and the western part of the Mid-Beskidy Foothills (Rożnów and Ciężkowice Foothills) are mostly built of deposits of the Silesian Nappe and the underlying Sub-Silesian Nappe. These areas are drained by the Soła, Skawa, Raba, and Dunajec rivers. The eastern part of the Mid-Beskidy Foothills, on the other hand, is made up of the Skole Nappe and Miocene deposits.

The subcarpathian basin reaches of the main Carpathian rivers best reflect the increasing length of rivers from west to east. The shortest crossing of the subcarpathian basin is that of the Skawa which flows through the Upper Vistula Valley mesoregion which belongs to the Oświęcim Basin macroregion. This mesoregion has a small longitudinal extent $(12.5 \mathrm{~km})$ at the mouth of the Skawa. Successive rivers, starting from the Raba, flow into the Vistula in the Sandomierz Basin macroregion, the longitudinal extent of which increases from $18.7 \mathrm{~km}$ (the mouth of the Raba) to $78.2 \mathrm{~km}$ (the mouth of the San). The Soła, before entering the mesoregion of the Upper Vistula Valley, flows through the Wilamowice Submontane Region, which also belongs to the Oświęcim Basin. The longitudinal extent of the basin at the Sola mouth is $26 \mathrm{~km}$. These conditions enabled the development of the most extended reach of an anabranching channel in the entire study area. The anabranching-type channels in the Soła and Skawa basin reaches were also possible due to the higher values of the valley floor drop in elevation, which exceed $2 \%$, while in the remaining rivers they range between $0.41 \%$ and $0.84 \%$.

\subsection{Other Factors Controlling Types of Channel Pattern}

The hydroclimatic conditions determining the discharge volumes in the channels and their energy have been well recognised in the Polish Carpathians. According to Ziemońska [39], the Carpathians are divided into the western macroregion (catchments from the Soła to the Dunajec), richer in water resources, with less found in the eastern macroregion (catchments from the Wisłoka to the San). The rivers of the western macroregion have their greatest runoff in the months of June-August, and floods occur during the summer months. The rivers of the eastern macroregion show features of a more continental regime than the rivers of the western part of the study area, with the highest runoff in March-May. They are characterized by no regular summer floods and low water levels in August-October [51].

Carpathian rivers are characterized by an uneven hydrological regime along with the inflow of rainwater, groundwater, and snow [52]. Except for the Dunajec, all Carpathian rivers have nivo-pluvial regimes, characterised by an extensive range of annual outflow. The underground water supply is small and fluctuates between $20 \%$ and $40 \%$, while daily discharges are highly volatile. The Dunajec river is distinguished by a pluvio-nival regime, which has the largest range of annual and daily outflow. The underground water supply does not exceed $40 \%$ [53]. The most significant impact on the diversity of precipitation and runoff are absolute and relative elevations and the size of the catchment area (Table 4). The hydrometeorological conditions favoured more intensive sediment supply and more efficient bedload transport in the western part of the Carpathians.

Table 4. Mean annual discharge from the Carpathian rivers catchment area in 2020.

\begin{tabular}{cccccccc}
\hline $\begin{array}{c}\text { River, } \\
\text { Gauging Station }\end{array}$ & $\begin{array}{c}\text { Soła, } \\
\text { Oświęcim }\end{array}$ & $\begin{array}{c}\text { Skawa, } \\
\text { Zator }\end{array}$ & $\begin{array}{c}\text { Raba, } \\
\text { Proszówki }\end{array}$ & $\begin{array}{c}\text { Dunajec, } \\
\text { Żabno }\end{array}$ & $\begin{array}{c}\text { Wisłoka, } \\
\text { Mielec }\end{array}$ & $\begin{array}{c}\text { Wisłok, } \\
\text { Tryńcza }\end{array}$ & $\begin{array}{c}\text { San, } \\
\text { Radomyśl }\end{array}$ \\
\hline runoff $\left(\mathrm{m}^{3} / \mathrm{s}\right)$ & 23.1 & 13.5 & 15.9 & 95 & 30.3 & 24.7 & 132 \\
\hline
\end{tabular}

The gauging stations closest to the mouths of the rivers have been selected. Source: Polish Institute of Meteorology and Water ManagementNational Research Institute https:/ / danepubliczne.imgw.pl/ (accessed 14 December 2021). 
The conclusion of Fal [54] is essential for an analysis of historical channel patterns. This states that in the years 1900-1990 in Poland, there were no statistically significant changes in runoff and precipitation. Later studies confirm that all Carpathian rivers had stable features of runoff regime in the 1951-2010 period [55]. This proves that the hydroclimatic conditions in the twentieth century are relatively constant. However, in the nineteenth century, towards the end of the Little Ice Age [20], much more rainfall favoured the formation of multi-thread channels.

Land use in the Carpathians changed in the nineteenth century, with deforestation being the main trend. Until World War I, the proportion of forest in the Carpathians fell from $28 \%$ in $1815 \%$ to $25 \%$ in 1913 [56]. The analysis of forest cover in the Polish Carpathians $[57,58]$ carried out, based on the same map used in this study, indicates a figure of $27 \%$ forest. According to detailed data, the average proportion of forest in the Western Beskidy Foothills was 15\%, Western Beskidy 23\%, and the Orawa-Nowy Targ Basin and Tatra Range $23 \%$. However, in the eastern part of the region, the proportion of forests was higher, the Mid-Beskid Foothills at 23\%, and Mid Beskidy and Lesiste Beskidy at $35 \%$. Within macroregions, forest cover increased from north to south along with an increase in absolute height [57,58]. Man-made deforestation has been the controlling factor affecting the increased sediment supply to the Carpathian rivers [32]. This process, which lasted from the 16th century [19], led to the development of multi-thread channel patterns. Deforestation was the factor that prevented the Carpathian channels from functioning in the nineteenth century in natural conditions.

Until the nineteenth century, the only direct human impact on the channel patterns was limited to local training works. One of the regulated channels was the riverbed of the lower Dunajec which was created by digging through two meander loops. This is the first cartographic evidence of the commencement of regulatory works in the second half of the nineteenth century. As a result of these works, two large inter-canal areas were created, forming the anthropogenic anastomosis.

\section{Discussion}

The historical map of Galicia and Bucovina (1861-1864)—the Second military survey of the Habsburg Empire used in the study, made it possible to correctly analyse nineteenth-century river channel patterns in the northern Carpathians. According to Hohensinner et al. [10], despite the uncertainty of the exact location of specific points on historical maps, they remain the only source of information about channel patterns at the regional scale. However, Vichrova [42] considers that in the Second military survey of the Habsburg Empire map, the relief and the location of specific points were presented accurately and without distortion. Historical Austrian maps were considered a good source of information on river geomorphology in the nineteenth century [16]. Bravard and Bethemont [59] and Hohensinner et al. [60] argue that using successive Austrian military surveys, one can analyse the transformation of channel patterns in the eighteenth and nineteenth centuries. In addition, these studies have proven that the accuracy of the mapping of the river bed and floodplain forms allows for a reliable reconstruction of the channel pattern.

The results of previous studies on channel patterns $[7,61-63]$ present that each channel type is characterized by the domination of bedload or suspended transport and the presence of gravel, sand, or silt bed. However, these features do not uniquely differentiate the channel patterns [64]. Thus, for example, the anabranching system cannot be associated with silt-bed rivers. A distinctive feature of multi-thread patterns is the presence of inter-channel areas, forms of valley floor which are treated as floodplains in hydraulic analyses $[50,65]$. Thus, a key element of research on the delimitation of a pattern type is the study of forms surrounded by flowing water. This means that even those with an area of several hundred square meters can be identified as inter-channel areas if the river has anabranching characteristics (for example, the Moravka in Czechia [19]). To qualify, these forms must be stabilised by vegetation [66]. According to Nanson and Knighton [62], inter-channel forms should have a surface composed of fine-grained sediments. However, 
Smith [67] considers that the stability of channel and inter-channel forms are primarily determined by vegetation. The results from a study of islands in the Carpathian rivers [68] may serve as confirmation of these views. The cited research results confirm the correctness and usefulness of morphometric analysis in classifying channel patterns based on maps. On the basis of morphometric analyses using maps, a limited but sufficient number of river channel features can be investigated. This method allows for the separation of braided channels from anabranching ones, contrary to the opinion that historical maps allow only multi-thread channels in general to be delimited [10]. Moreover, the morphometric method ensures repeatability of the research and significantly reduces the subjectivity of evaluations made by the researcher [49]. Moreover, the division of the mid-channel forms into bars, islands and inter-channel areas is justified hydraulically [50].

In this study it was found that the morphometric parameters proposed by Brice and Blodgett [49], and adapted by Teisseyre [50] to gravel-bed rivers, were correctly established. Even within relatively small areas, mid-channel forms with buildings confirm their stability and elevation above flood level and have always been classified as inter-channel areas. In the case of short anabranching reaches, it should be emphasised that their delimitation is supported by the ratio of the size of the inter-channel area to channel width [49] and the fact that they have been stabilised with vegetation [67]. These elements determine the overall stabilisation of an entire reach $[69,70]$.

The mountain rivers in their upper parts have sinuous channels, which in the middle course return to braided and anabranching ones, so that the lowermost course, a sinuous or meandering form, is developed [71,72]. However, many authors indicate frequent exceptions to this rule both on the scale of entire rivers $[10,73,74]$ and in reaches $[75,76]$. In the study area, deviations from the scheme are visible in (I) the dominance of multi-thread reaches in most river courses in the western part of the study area; (II) the domination of sinuous reaches in all rivers in the eastern part of the study area; (III) the appearance of anabranching reaches on all parts of a river; (IV) intramontane basins with varied multi-thread reaches that would not appear in mountain courses.

The main reason for the dominance of multi-thread reaches in the western part of the study area and the dominance of sinuous sections in the east is the geological structure and the resulting orography. The much higher energy of the relief in the west favours a greater sediment supply than for the eastern rivers. A higher supply of gravel is usually associated with the Magura Nappe [32]. In general terms, this was confirmed in this work, but the examples of the Skawa and Wisłoka show that the tendency to braiding cannot be directly associated with the Magura Nappe. General analyses indicate that braided rivers occur mainly in catchments formed by sedimentary rocks $[77,78]$. However, detailed studies have confirmed this for only some rivers [79]. This proves that the analysis of the influence of lithology on the development of a channel pattern should be investigated each time together with other factors as making generalisations is imprecise. Moreover, differences in the geological structure of the catchment area do not determine channel patterns because the valleys mostly have floors filled with thick layers of gravel accumulated during glacial periods. The direct influence of glaciers and the ice sheet on the Carpathian valleys was small. Glacial relief is only found in the Tatra Mountains [80] and on the northern slopes of Babia Góra [81], and it did not significantly influence the diversity of channel patterns. This factor, which is very important in analysing patterns in areas glaciated today [10], is in practice irrelevant in the case of the Carpathians.

An important factor determining the type of channel, depending on the geological structure, is their slope [82]. As the drop increases, the sinuosity of the channel increases up to a critical point at which braiding begins [83]. Leopold and Wolman [84] showed that change in the type of channel pattern depends on the relation of the drop to the flow rate. For this reason, there are no fixed drop values assigned to specific types of transformation [85]. In the case of analyses of channel patterns carried out on historical maps, measurement of channel slope is impossible. The value partially explaining it is the slope of the valley floor. However, analyses indicate that there is no relation between 
slope and pattern. According to Doeglas [86], flow rate and flow variability have a greater impact. However, these views are also questioned [87].

Among land use forms, forests have the most significant impact on flow dynamics and the forming of a channel pattern $[23,88]$. However, the greatest impact on land cover changes, especially deforestation, is attributed to man [89]. The eastern part of the study area was more forested than the western in the nineteenth century [56,57], favouring less gravel supply from the catchment and consequently reducing the potential of eastern rivers to develop multi-thread patterns. Some authors associate the emergence of braided channels in the Carpathians with the deforestation that started in the sixteenth century $[19,90]$ and intensified in the nineteenth [91]. There was also more intense precipitation associated with the Little Ice Age, which was conducive to braiding [20].

The diversification of hydrometeorological conditions favoured more intensive sediment supply and more efficient bedload transport in the western part of the Carpathians. The flow regimes determine the channel patterns [1]. This general assumption has been undermined however in studies of anabranching channels which developed despite the high hydrological inertia of rivers (large differences between low and high flows) [12,62,92]. Therefore, there were hydrometeorological conditions due to the existence of different types of channel pattern immediately next to each other. Some authors present the extreme position that channel pattern is not related to climate $[25,93]$.

Locally, point causes influenced the initiation of numerous anabranching reaches with only one inter-channel area in the mountain courses. This is confirmed by the fact that the most significant number of short anabranching reaches were found in the upper courses of the San. In this area, fine-grained alluvial material of great depth covering gravel or rock forms are found, associated with aggradation due to the intensification of the human economy in the Middle Ages [94]. The correlation of this process with the undulating geological structure of the area indicates that the inter-channel areas may have arisen in places of uneroded rock thresholds or landslides [95], which forced avulsion and subsequent deposition. Short multi-thread reaches were identified downstream of tributary mouths, regardless of their location in the course of a river. Mouths usually cause discontinuities in channel patterns [96] which disappear downstream [97]. The change in the unit power of a stream in combination with an increase in average grain size of the sediment is usually associated with the commencement or intensification of braiding in a mountain river [98].

Multi-thread reaches dominate river channels across intramontane basins, formed due to the deposition of sediment carried by the main river. The loss of the transport capacity of a river after leaving its mountain valley into a much more expansive floodplain favours the formation of this type of channel $[18,99]$. The width of the valley floor is also related to the presence of sediment slug, which is a local source of gravel for multi-thread channels [28].

In the nineteenth century, all the analysed rivers had unchannelized patterns, in which human pressure was limited to the local regulation of water intake for watermills or the protection of river crossings [100]. The conclusions of the cartographic analyses are confirmed by historical sources [12,34]. The only exception found during the research was excavation across meander bends in the lower reaches of the Dunajec River which led to the creation of an artificial anabranching channel. Such channels are referred to as anthropogenic anastomoses [101].

Based on morphometric analysis, it can be concluded that in the nineteenth century the main rivers in the northern part of the Carpathians had mainly multi- (in the western part) and single-thread (in the eastern part) channels. The Soła can be called an anabranching river because its channel was dominated by reaches with forms stabilised by vegetation. The braided reaches of the Soła river [26] indicated in the literature constituted the discontinuity of anabranching channels and were usually braided with islands. The Raba was a braided river with a meandering lower course. The existence of short anabranching reaches in the foothills was already postulated by Wyżga [27] and this study confirms the thesis concerning the braiding of the historical Raba $[27,102]$. The Dunajec was an anabranching 
river, determined by long reaches in intramontane basins and foothills. The presence of historical braided reaches or braided with islands indicated in the literature $[29,103,104]$ was confirmed in this study. The nineteenth-century Skawa was a sinuous river with an anabranching channel in its lower course. The differences between the Skawa and the rivers in the western part of the studied area result from its source region, which has the lowest relief energy in the western Carpathians [105]. The Skawa's tendency to develop a multi-thread pattern [106] is evidenced by its anabranching reaches downstream of its main tributaries. In the eastern part of the study area, all three rivers had mainly sinuous channels, in the nineteenth century. The Wisłoka was a sinuous river [107] with a braided reach in its lower course. The Wisłok had the least diversified channel among all those studied, although it had a braided lowermost reach. On the other hand, the San had a sinuous channel [31] with a meandering and braiding lower course.

\section{Conclusions}

1. The nineteenth-century map of Galicia and Bucovina (1861-1864)—Second military survey of the Habsburg Empire enables the study of historical relief, including the identification of river channel functioning.

2. Morphometric analysis has been verified as a tool to carry out an objective classification of channel patterns based on historical maps.

3. In the rivers of the western part of the study area (Soła-Dunajec), multi-thread channels were dominant in the nineteenth century, especially anabranching systems with braided side channels. Single-thread channels dominated the rivers in the eastern part (Wisłoka-San).

4. Higher relief energy, higher precipitation, more frequent floods, and a smaller proportion of forests in land cover favoured the activation of sediment and the formation of multi-thread reaches in the western part of the study area.

5. The formation of individual reaches was determined by combinations of geological, orographic, and hydroclimatic factors creating specific local conditions. Most important for multi-thread reaches was the high supply or availability of gravel on the valley floor.

Funding: This research was funded by Pedagogical University of Krakow Project No. BN.610-334/ PBU/2020. The APC was funded by Pedagogical University of Krakow Project No. BN.302.233.2021.RN.

Institutional Review Board Statement: Not applicable.

Informed Consent Statement: Not applicable.

Data Availability Statement: Publicly available datasets were analyzed in this study.

Conflicts of Interest: The author declares no conflict of interest. 


\section{Appendix A}

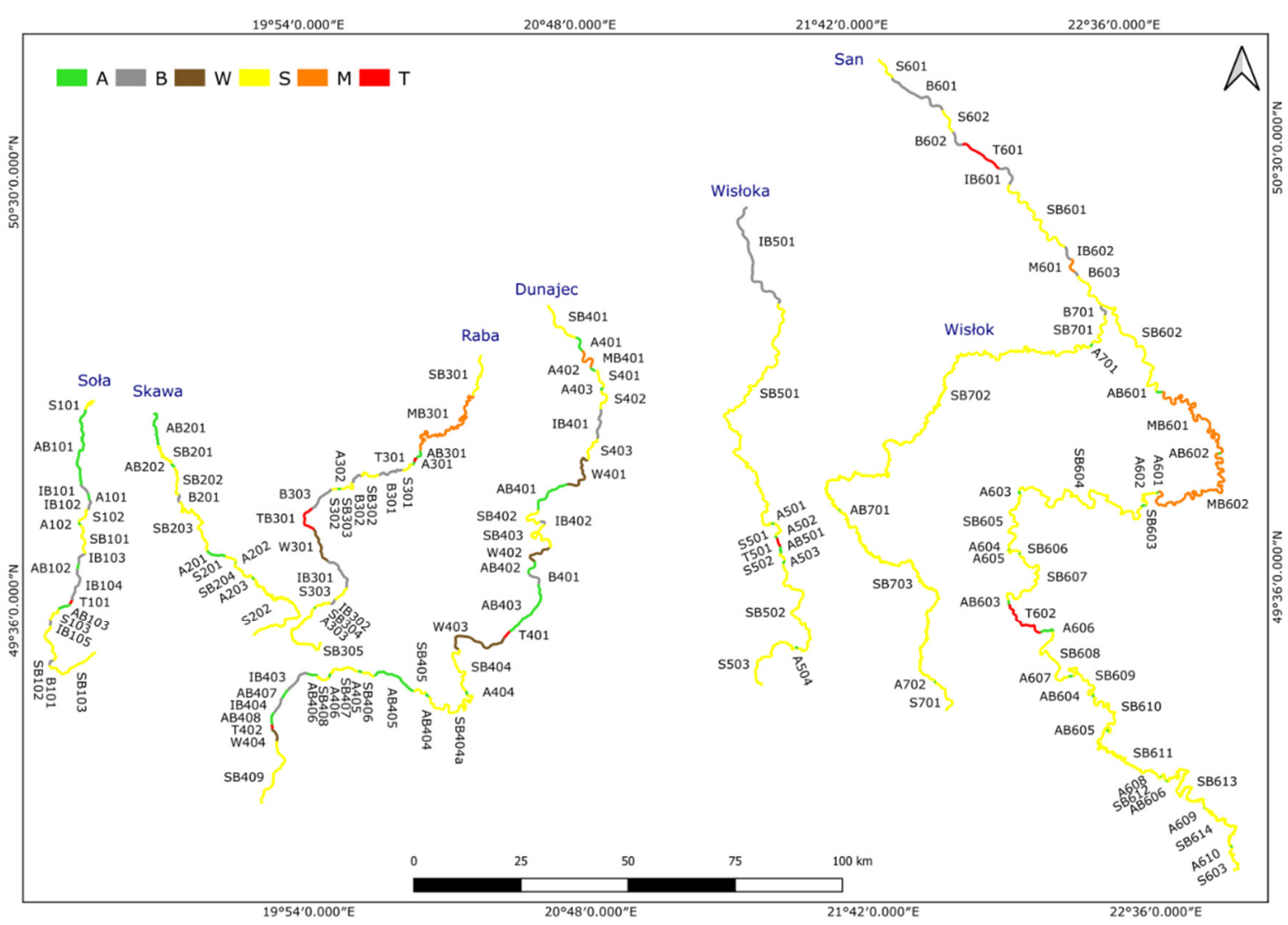

Figure A1. Division of the channel reaches of the studied rivers into anabranching (A), braiding (B), wandering (W), sinuous (S), meandering $(\mathrm{M})$ and straight $(\mathrm{T})$ channel patterns. For multi-thread reaches, the Table A1 shows the number of mid-channel forms broken down into bars, islands, and inter-channel areas.

Table A1. The number of mid-channel forms broken down into bars, islands, and inter-channel areas for multi-thread reaches.

\begin{tabular}{|c|c|c|c|c|c|c|c|c|c|c|c|c|c|c|}
\hline \multirow{2}{*}{ River } & \multirow{2}{*}{ Reach } & \multicolumn{3}{|c|}{ Mid-Channel Form } & \multirow{2}{*}{ River } & \multirow{2}{*}{ Reach } & \multicolumn{3}{|c|}{ Mid-Channel Form } & \multirow{2}{*}{ River } & \multirow{2}{*}{ Reach } & \multicolumn{3}{|c|}{ Mid-Channel Form } \\
\hline & & Bar & Island & Area & & & Bar & Island & Area & & & Bar & Island & Area \\
\hline \multirow{11}{*}{$\begin{array}{l}\frac{\pi}{0} \\
\text { के }\end{array}$} & A101 & & & 2 & \multirow{11}{*}{ 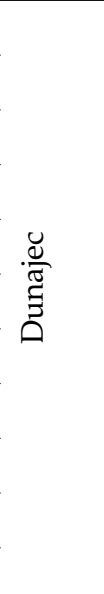 } & A401 & & & 2 & \multirow{6}{*}{$\frac{\frac{\tilde{v}}{0}}{\frac{\pi}{\tilde{n}}}$} & A501 & & & 1 \\
\hline & A102 & & & 1 & & A402 & & & 1 & & A502 & & & 1 \\
\hline & AB101 & 11 & 4 & 19 & & A403 & & & 1 & & A503 & & & 1 \\
\hline & AB102 & 3 & 3 & 2 & & A404 & & & 1 & & A504 & & & 1 \\
\hline & AB103 & 1 & 1 & 5 & & A405 & & & 1 & & AB501 & 1 & & 2 \\
\hline & B101 & 4 & & & & A406 & & & 1 & & IB501 & 59 & 6 & \\
\hline & IB101 & 4 & 1 & & & AB401 & 4 & 7 & 9 & \multirow{5}{*}{$\begin{array}{l}\text { సే } \\
\text { ஸి }\end{array}$} & A601 & & & 1 \\
\hline & IB102 & 1 & 3 & & & AB402 & 1 & & 3 & & A602 & & & 1 \\
\hline & IB103 & 6 & 1 & & & AB403 & 18 & 17 & 16 & & $\mathrm{~A} 603$ & & & 1 \\
\hline & IB104 & 27 & 2 & 1 & & AB404 & & 1 & 2 & & A604 & & & 1 \\
\hline & IB105 & 4 & 1 & & & AB405 & 22 & 1 & 17 & & A605 & & & 1 \\
\hline
\end{tabular}


Table A1. Cont.

\begin{tabular}{|c|c|c|c|c|c|c|c|c|c|c|c|c|c|c|}
\hline \multirow{2}{*}{ River } & \multirow{2}{*}{ Reach } & \multicolumn{3}{|c|}{ Mid-Channel Form } & \multirow{2}{*}{ River } & \multirow{2}{*}{ Reach } & \multicolumn{3}{|c|}{ Mid-Channel Form } & \multirow{2}{*}{ River } & \multirow{2}{*}{ Reach } & \multicolumn{3}{|c|}{ Mid-Channel Form } \\
\hline & & Bar & Island & Area & & & Bar & Island & Area & & & Bar & Island & Area \\
\hline \multirow{6}{*}{ 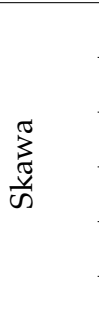 } & A201 & & & 5 & & AB406 & 5 & 1 & 4 & & A606 & & & 2 \\
\hline & A202 & & & 1 & & AB407 & 6 & & 1 & & $\mathrm{~A} 607$ & & & 1 \\
\hline & A203 & & & 1 & & AB408 & 2 & 7 & 2 & & A608 & & & 1 \\
\hline & AB201 & 17 & 1 & 5 & & B401 & 12 & & & & A609 & & & 1 \\
\hline & AB202 & 2 & & 1 & & IB401 & 4 & 3 & & & A610 & & & 1 \\
\hline & B201 & 5 & & & & IB402 & 3 & 1 & & & AB601 & 1 & & 1 \\
\hline \multirow{10}{*}{$\begin{array}{l}\tilde{\sigma} \\
\tilde{\tilde{\pi}} \\
\tilde{\simeq}\end{array}$} & A301 & & & 1 & & IB403 & 11 & 3 & & & AB602 & 1 & 1 & 1 \\
\hline & A302 & & & 1 & & IB404 & 6 & & 2 & & AB603 & 1 & & 1 \\
\hline & A303 & & & 1 & & W401 & 12 & & 2 & & AB604 & & 1 & 1 \\
\hline & AB301 & & 1 & 1 & & W402 & 9 & & 1 & & AB605 & 1 & & 1 \\
\hline & B301 & 6 & & & & W403 & 9 & 5 & 5 & & AB606 & & 1 & 1 \\
\hline & B302 & 6 & & & & W404 & 4 & 1 & 3 & & B601 & 12 & & \\
\hline & B303 & 7 & & & \multirow{4}{*}{$\frac{\frac{y}{0}}{\frac{10}{5}}$} & A701 & & & 1 & & B602 & 7 & & \\
\hline & IB301 & 10 & 11 & & & A702 & & & 1 & & B603 & 3 & & \\
\hline & IB302 & 8 & & 1 & & AB701 & 1 & & 1 & & IB601 & 6 & 1 & \\
\hline & W301 & 4 & 2 & 7 & & B701 & 5 & & & & IB602 & 3 & 1 & \\
\hline
\end{tabular}

Table A2. River reaches of various channel pattern types (as indicated in the text), broken down into parts of river courses (B-subcarpathian basin, F-foothill, M-mountain, MB —intramontane basin), according to the length and number of reaches.

\begin{tabular}{|c|c|c|c|c|c|c|c|c|c|c|c|c|c|c|c|c|c|c|c|c|c|c|c|c|c|}
\hline \multirow{2}{*}{ River } & \multirow{2}{*}{$\begin{array}{l}\text { River } \\
\text { Course }\end{array}$} & \multirow{2}{*}{ Total } & \multicolumn{11}{|c|}{ Length of Reaches (km) } & \multirow{2}{*}{ Total } & \multicolumn{11}{|c|}{ Number of Reaches } \\
\hline & & & $\mathbf{A}$ & AB & B & IB & W & $\mathrm{S}$ & SB & $\mathbf{M}$ & MB & $\mathbf{T}$ & ТВ & & $\mathbf{A}$ & $\mathbf{A B}$ & B & IB & $\mathbf{W}$ & $S$ & SB & $\mathbf{M}$ & MB & $\mathbf{T}$ & TB \\
\hline \multirow{5}{*}{ Soła } & whole & 92.3 & 2.2 & 25.1 & 1.7 & 18.3 & & 11.9 & 32 & & & 1.1 & & 18 & 2 & 3 & 1 & 5 & & $3 *$ & 3 & & & 1 & \\
\hline & B & 27.4 & & 20.6 & & 2.7 & & 4.1 & & & & & & 3 & & 1 & & 1 & & 1 & & & & & \\
\hline & $\mathrm{F}$ & 4.1 & 1.5 & & & 2.6 & & & & & & & & 2 & 1 & & & 1 & & & & & & & \\
\hline & $\mathrm{M}$ & 42.4 & 0.7 & & 1.7 & 1.5 & & 6.5 & 32 & & & & & 8 & 1 & & 1 & 1 & & 2 & 3 & & & & \\
\hline & $\mathrm{BM}$ & 18.3 & & 4.5 & & 11.4 & & 1.3 & & & & 1.1 & & 5 & & 2 & & 2 & & 1 & & & & 1 & \\
\hline \multirow{5}{*}{ Skawa } & whole & 98.2 & 5.6 & 10 & 1.9 & & & 40.5 & 40.2 & & & & & 12 & 3 & 2 & 1 & & & 2 & 4 & & & & \\
\hline & B & 8.8 & & 8.8 & & & & & & & & & & 1 & & 1 & & & & & & & & & \\
\hline & $\mathrm{F}$ & 15.9 & & 1.2 & & & & & 14.7 & & & & & 3 & & 1 & & & & & 2 & & & & \\
\hline & $\mathrm{M}$ & 73.6 & 5.6 & & 1.9 & & & 40.5 & 25.6 & & & & & 8 & 3 & & 1 & & & 2 & 2 & & & & \\
\hline & BM1 & & & & & & & & & & & & & & & & & & & & & & & & \\
\hline \multirow{4}{*}{ Raba } & whole & 137.5 & 1.9 & 2.4 & 16.4 & 10.7 & 8.6 & 9 & 46.5 & & 33.5 & 1.2 & 7.3 & 21 & 3 & 1 & 3 & 2 & 1 & 3 & 5 & & $\begin{array}{l}1 \\
*\end{array}$ & 1 & 1 \\
\hline & B & 39 & & & & & & & 11 & & 28 & & & 2 & & & & & & & 1 & & 1 & & \\
\hline & $\mathrm{F}$ & 41.8 & 1.4 & 2.4 & 16.4 & & & 4.8 & 10.1 & & 5.5 & 1.2 & & 11 & 2 & 1 & 3 & & & 2 & 2 & & 1 & 1 & \\
\hline & $\begin{array}{c}\mathrm{M} \\
\mathrm{BM}\end{array}$ & 56.7 & 0.4 & & & 10.7 & 8.6 & 4.2 & 25.5 & & & & 7.3 & 8 & 1 & & & 2 & 1 & 1 & 2 & & & & 1 \\
\hline \multirow{5}{*}{ Dunajec } & whole & 254.6 & 9.1 & 49.5 & 4 & 19.9 & 39.4 & 17.2 & 105.1 & & 7.3 & 3.1 & & 39 & 6 & 8 & 1 & 4 & 4 & $3 *$ & 10 & & 1 & 2 & \\
\hline & B & 45.3 & 6.2 & & & 7.6 & & 13.2 & 11 & & 7.3 & & & 8 & 3 & & & 1 & & 3 & 1 & & 1 & & \\
\hline & $\mathrm{F}$ & 59.3 & & 14.3 & & 1.5 & 19.1 & 4 & 20.4 & & & & & 8 & & 2 & & 1 & 2 & 1 & 2 & & & & \\
\hline & $\mathrm{M}$ & 59.5 & 1 & & & & 3.4 & & 55.1 & & & & & 5 & 1 & & & & 1 & & 3 & & & & \\
\hline & $\mathrm{BM}$ & 90.5 & 1.9 & 35.2 & 4 & 10.8 & 16.9 & & 18.6 & & & 3.1 & & 18 & 2 & 6 & 1 & 2 & 1 & & 4 & & & 2 & \\
\hline \multirow{5}{*}{ Wisłoka } & whole & 170.6 & 2.8 & 1.7 & & 29.1 & & 27.3 & 107.5 & & & 2.2 & & 12 & 4 & 1 & & 1 & & $3 *$ & 2 & & & 1 & \\
\hline & B & 68.5 & & & & 29.1 & & & 39.4 & & & & & 2 & & & & 1 & & & 1 & & & & \\
\hline & $\mathrm{F}$ & 39.4 & 0.7 & & & & & 2.4 & 36.3 & & & & & 2 & 1 & & & & & 1 & 1 & & & & \\
\hline & $\mathrm{M}$ & 53.3 & 0.7 & & & & & 20.8 & 31.8 & & & & & 3 & 1 & & & & & 1 & 1 & & & & \\
\hline & $\mathrm{BM}$ & 9.5 & 1.4 & 1.7 & & & & 4.2 & & & & 2.2 & & 5 & 2 & 1 & & & & 2 & & & & 1 & \\
\hline
\end{tabular}


Table A2. Cont.

\begin{tabular}{|c|c|c|c|c|c|c|c|c|c|c|c|c|c|c|c|c|c|c|c|c|c|c|c|c|c|}
\hline \multirow{2}{*}{ River } & \multirow{2}{*}{$\begin{array}{l}\text { River } \\
\text { Course }\end{array}$} & \multirow{2}{*}{ Total } & \multicolumn{11}{|c|}{ Length of Reaches (km) } & \multirow{2}{*}{ Total } & \multicolumn{11}{|c|}{ Number of Reaches } \\
\hline & & & $\mathbf{A}$ & $\mathbf{A B}$ & B & IB & $\mathbf{W}$ & S & SB & $\mathbf{M}$ & MB & $\mathbf{T}$ & TB & & $\mathbf{A}$ & $\mathbf{A B}$ & B & IB & W & S & SB & $\mathbf{M}$ & MB & $\mathbf{T}$ & TB \\
\hline \multirow{4}{*}{ San } & whole & 495 & 8.2 & 4.8 & 21.1 & 9.8 & & 20.9 & 319 & 4.1 & 84.3 & 22.8 & & 43 & 10 & 6 & 3 & 2 & & 3 & 14 & 1 & 2 & 2 & \\
\hline & B & 201 & & 2 & 21.1 & 9.8 & & 11.7 & 68.9 & 4.1 & 72.7 & 10.7 & & 15 & & 2 & 3 & 2 & & 2 & 2 & 1 & 2 & 1 & \\
\hline & $\mathrm{F}$ & 146.6 & 6.7 & 0.9 & & & & & 115.3 & & 11.6 & 12.1 & & 13 & 6 & 1 & & & & & 6 & & 1 & 1 & \\
\hline & $\begin{array}{c}\mathrm{M} \\
\mathrm{BM}\end{array}$ & 147.4 & 1.6 & 1.8 & & & & 9.3 & 134.7 & & & & & 15 & 4 & 3 & & & & 1 & 7 & & & & \\
\hline \multirow{5}{*}{ Wisłok } & whole & 229.3 & 1.1 & 0.3 & 3 & & & 10.4 & 214.5 & & & & & 8 & 2 & 1 & 1 & & & 1 & $\begin{array}{l}3 \\
*\end{array}$ & & & & \\
\hline & B & 66.6 & 0.8 & & 3 & & & & 62.8 & & & & & 4 & 1 & & 1 & & & & 2 & & & & \\
\hline & $\mathrm{F}$ & 79 & & 0.3 & & & & & 78.7 & & & & & 1 & & 1 & & & & & 2 & & & & \\
\hline & $\mathrm{M}$ & 29.1 & 0.4 & & & & & 10.4 & 18.3 & & & & & 2 & 1 & & & & & 1 & 1 & & & & \\
\hline & BM & 54.7 & & & & & & & 54.7 & & & & & 1 & & & & & & & 1 & & & & \\
\hline
\end{tabular}

${ }^{*}$ the values do not add up because some reaches are located in two parts of a river and have been counted twice.

Table A3. Proportion (\%) of reaches according to their channel pattern types (as indicated in the text). The lack columns indicate the proportion of reaches that started from its source or ended at a mouths.

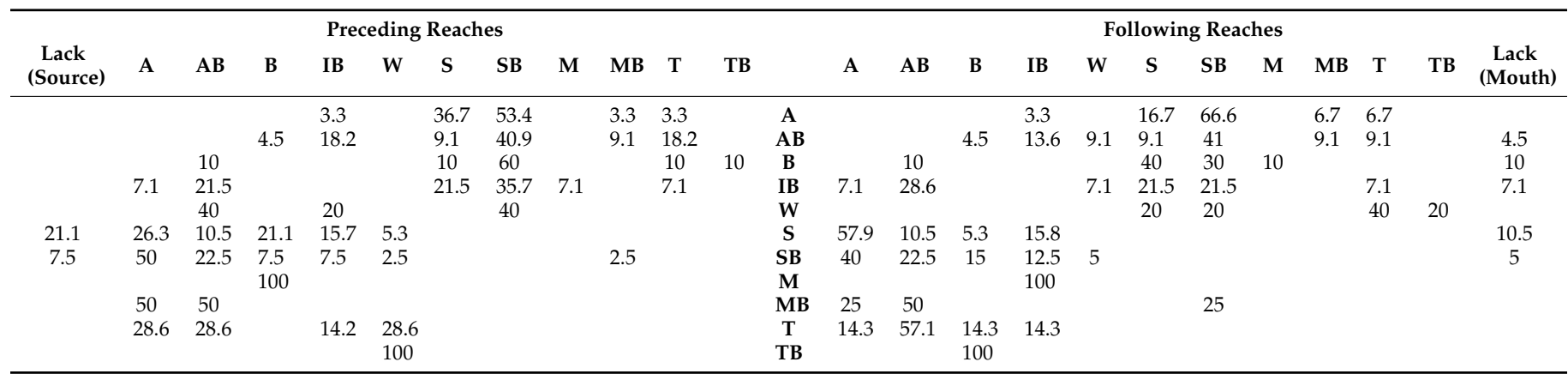

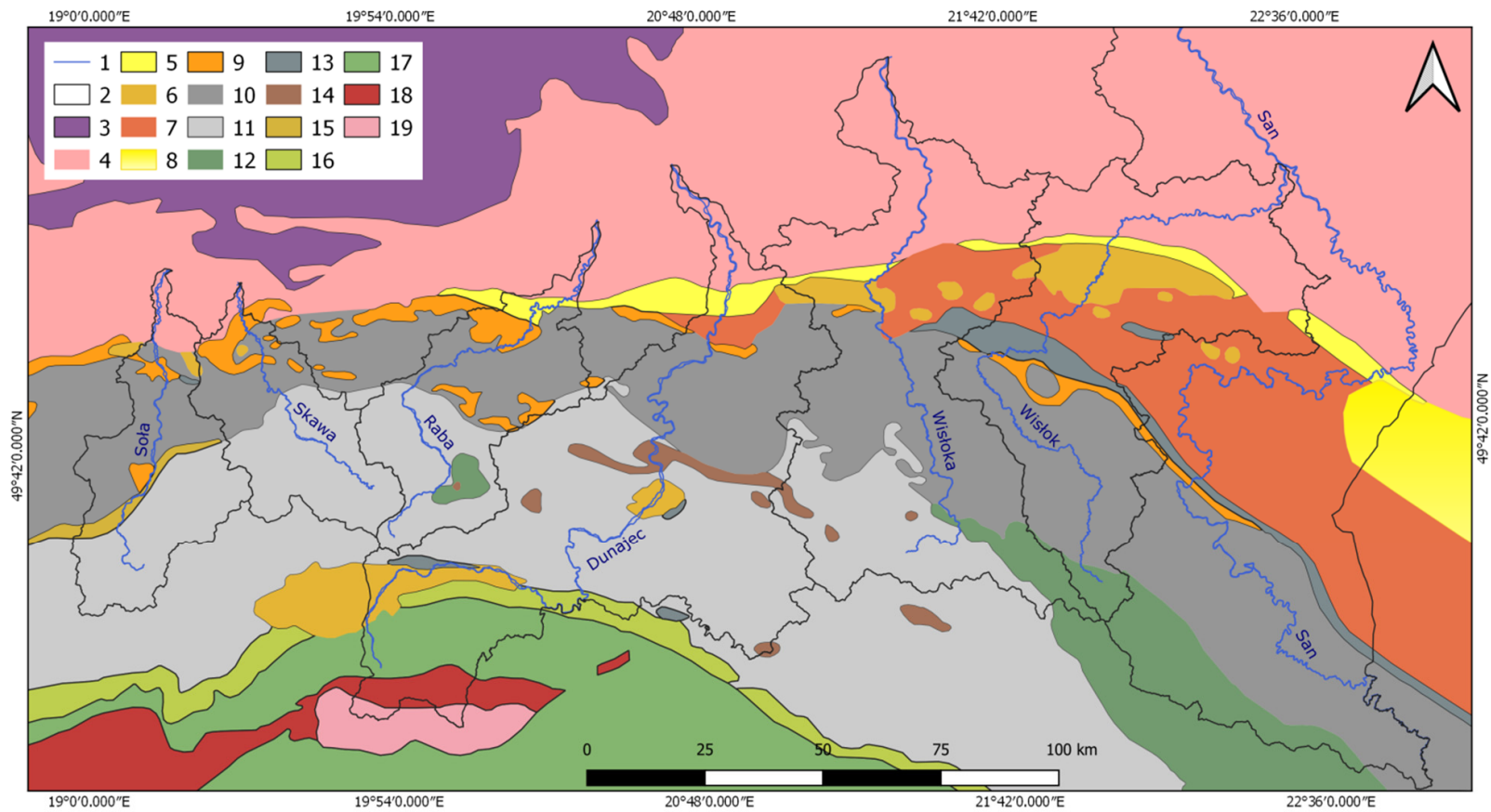

Figure A2. A simplified geological map. Based on Oszczypko, Ślączka \& Żytko [44]. 1—river, 2-catchment, 3-Carpathian Foreland, 4-Miocene of the Carpathian Foredeep, 5-Zglobice Thrust-sheets, 6-Miocene deposits upon the Carpathians, 7-Skole Nappe, 8-Stebnik Nappe, 9-Sub-Silesian Nappe, 10—Silesian Nappe, 11-Magura Nappe, 12—Dukla Nappe, 13-Lower Miocene, 14-Grybow Sub-Nappe, 15-Fore-Magura Thrust-sheets, 16-Pieniny Klippen Belt, 17-Inner Carpathians Paleogene Basin, 18-Mesozoic of the Inner Carpathians, 19-Crystaline core of the Tatra Mountains. 


\section{References}

1. Buffington, J.M.; Montgomery, D.R. Geomorphic classification of rivers. In Treatise on Geomorphology; Fluvial Geomorphology; Shroder, J., Wohl, E., Eds.; Academic Press: San Diego, CA, USA, 2013; Volume 9, pp. 730-767.

2. Schumm, S.A. The Fluvial System; John Wiley and Sons: New York, NY, USA, 1977.

3. Montgomery, D.R. Process domains and the river continuum. JAWRA J. Am. Water Resour. Assoc. 1999, 35, 397-410. [CrossRef]

4. Brierley, G.J.; Fryirs, K.A. Geomorphology and River Management: Applications of the River Styles Framework; Blackwell: Oxford, UK, 2005.

5. Church, M. Bed material transport and the morphology of alluvial river channels. Annu. Rev. Earth Planet. Sci. 2006, 34, 325-354. [CrossRef]

6. Meshkova, L.V.; Carling, P.A. Discrimination of alluvial and mixed bedrock-alluvial multichannel river networks. Earth Surf. Process. Landf. 2013, 38, 1299-1316. [CrossRef]

7. Rinaldi, M.; Gurnell, A.M.; del Tánago, M.G.; Bussettini, M.; Hendriks, D. Classification of river morphology and hydrology to support management and restoration. Aquat. Sci. 2016, 78, 17-33. [CrossRef]

8. Nardini, A.; Brierley, G. Automatic river planform identification by a logical-heuristic algorithm. Geomorphology 2021, $375,107558$. [CrossRef]

9. Mandarino, A.; Pepe, G.; Cevasco, A.; Brandolini, P. Quantitative Assessment of Riverbed Planform Adjustments, Channelization, and Associated Land Use/Land Cover Changes: The Ingauna Alluvial-Coastal Plain Case (Liguria, Italy). Remote Sens. 2021, 13, 3775. [CrossRef]

10. Hohensinner, S.; Egger, G.; Muhar, S.; Vaudor, L.; Piégay, H. What remains today of pre-industrial Alpine rivers? Census of historical and current channel patterns in the Alps. River Res. Appl. 2021, 37, 128-149. [CrossRef]

11. Škarpich, V.; Hradecký, J.; Dušek, R. Complex transformation of the geomorphic regime of channels in the forefield of the Moravskoslezské Beskydy Mts.: Case study of the Morávka River (Czech Republic). Catena 2013, 111, 25-40. [CrossRef]

12. Witkowski, K. Man's impact on the transformation of channel patterns (the Skawa River, southern Poland). River Res. Appl. 2021, 37, 150-162. [CrossRef]

13. Scorpio, V.; Rosskopf, C.M. Channel adjustments in a Mediterranean river over the last 150years in the context of anthropic and natural controls. Geomorphology 2016, 275, 90-104. [CrossRef]

14. Bertrand, M.; Piégay, H.; Pont, D.; Liébault, F.; Sauquet, E. Sensitivity analysis of environmental changes associated with riverscape evolutions following sediment reintroduction: Geomatic approach on the Drôme River network, France. Int. J. River Basin Manag. 2013, 11, 19-32. [CrossRef]

15. Arnaud, F.; Schmitt, L.; Johnstone, K.; Rollet, A.-J.; Piégay, H. Engineering impacts on the Upper Rhine channel and floodplain over two centuries. Geomorphology 2019, 330, 13-27. [CrossRef]

16. Konias, A. Kartografia Topograficzna Ślaska Cieszyńskiego i Zaboru Austriackiego od II Połowy XVIII Wieku do Początku XX Wieku; Wyd. Uniwersytetu Śląskiego: Katowice, Poland, 2000.

17. Habersack, H.; Piégay, H. River restoration in the Alps and their surroundings: Past experience and future challenges. Dev. Earth Surf. Process. 2007, 11, 703-735. [CrossRef]

18. Scorpio, V.; Zen, S.; Bertoldi, W.; Surian, N.; Mastronunzio, M.; Dai Prá, E.; Zolezzi, G.; Comiti, F. Channelization of a large Alpine river: What is left of its original morphodynamics? Earth Surf. Process. Landf. 2018, 43, 1044-1062. [CrossRef]

19. Škarpich, V.; Horáček, M.; Galia, T.; Kapustová, V.; Šala, V. The effects of river patterns on riparian vegetation: A comparison of anabranching and single-thread incised channels. Morav. Geogr. Rep. 2016, 24, 24-31. [CrossRef]

20. Magny, M.; Arnaud, F.; Holzhauser, H.; Chapron, E.; Debret, M.; Desmet, M.; Leroux, A.; Millet, L.; Revel, M.; Vannière, B. Solar and proxy-sensitivity imprints on paleohydrological records for the last millennium in west-central Europe. Quat. Res. 2010, 73, 173-179. [CrossRef]

21. Kondolf, G.M.; Piegay, H.; Landon, N. Changes in the riparian zone of the lower Eygues River, France, since 1830. Landsc. Ecol. 2007, 22, 367-384. [CrossRef]

22. Zieliński, T. Sedymentologia. Osady Rzek i Jezior; Wyd. Nauk. Uniwersytetu im. Adama Mickiewicza w Poznaniu: Poznań, Poland, 2015.

23. Ortyl, B.; Ćwik, A.; Kasprzyk, I. What happens in a Carpathian catchment after the sudden abandonment of cultivation? Catena 2018, 166, 158-170. [CrossRef]

24. Werritty, A.; Leys, K.F. The sensitivity of Scottish rivers and upland valley floors to recent environmental change. CATENA 2001, 42, 251-273. [CrossRef]

25. Schumm, S.A. River Metamorphosis. J. Hydraul. Div. 1969, 95, 255-274. [CrossRef]

26. Woskowicz-Ślęzak, B.; Ślęzak, A. Zapis antropopresji w rzeźbie przedgórskiego odcinka dna doliny Soły. In Antropopresja w Wybranych Strefach Morfoklimatycznych-Zapis Zmian w Rzeźbie i Osadach; Łajczak, A., Ed.; Uniwersytet Śląski: Sosnowiec, Poland, 2012; pp. 441-452.

27. Wyżga, B. Funkcjonowanie systemu rzecznego środkowej i dolnej Raby w ostatnich 200 latach. Dok. Geogr. 1993, 6, 1-94.

28. Liro, M. Development of sediment slug upstream from the Czorsztyn Reservoir (southern Poland) and its interaction with river morphology. Geomorphology 2016, 253, 225-238. [CrossRef] 
29. Hajdukiewicz, M.; Wyżga, B.; Hajdukiewicz, H.; Mikuś, P. Photogrammetric reconstruction of changes in vertical river position using archival aerial photos: Case study of the Czarny Dunajec River, Polish Carpathians. Acta Geophys. 2019, 67, $1205-1221$. [CrossRef]

30. Klimek, K. Man's Impact on Fluvial Processes in the Polish Western Carpathians. Geogr. Ann. Ser. A Phys. Geogr. 1987, 69, 221-226. [CrossRef]

31. Hajdukiewicz, H.; Wyżga, B.; Zawiejska, J. Twentieth-century hydromorphological degradation of Polish Carpathian rivers. Quat. Int. 2019, 504, 181-194. [CrossRef]

32. Wyżga, B.; Zawiejska, J.; Hajdukiewicz, H. Multi-thread rivers in the Polish Carpathians: Occurrence, decline and possibilities of restoration. Quat. Int. 2016, 415, 344-356. [CrossRef]

33. Baumgart-Kotarba, M. Braided channel changes at chosen reaches of the Bialka river (the Podhale, Western Carpathians). Stud. Geomorphol. Carpatho-Balc. 1980, 14, 113-134.

34. Witkowski, K. The Galician Canal-An unrealized project that changed the rivers in the northern part of the Carpathians. River Res. Appl. 2021, 37( 9), 1343-1356. [CrossRef]

35. Storetvedt, K.M. The Tethys Sea and the Alpine-Himalayan orogenic belt; mega-elements in a new global tectonic system. Phys. Earth Planet. Inter. 1990, 62, 141-184. [CrossRef]

36. Solon, J.; Borzyszkowski, J.; Bidłasik, M.; Richling, A.; Badora, K.; Balon, J.; Brzezińska-Wójcik, T.; Chabudziński, Ł.; Dobrowolski, R.; Grzegorczyk, I.; et al. Physico-geographical mesoregions of Poland-Verification and adjustment of boundaries on the basis of contemporary spatial data. Geogr. Pol. 2018, 91, 143-170. [CrossRef]

37. Chlebowski, B.; Walewski, W. Słownik Geograficzny Królestwa Polskiego i Innych Krajów Słowiańskich. Tom X; Kasa im. Józefa Mianowskiego: Warszawa, Poland, 1889.

38. Cebulska, M.; Twardosz, R. Zmienność czasowa najwyższych miesięcznych sum opadów atmosferycznych w Polskich Karpatach Zachodnich (1951-2005). Pr. Geogr. 2012, 128, 123-134. [CrossRef]

39. Ziemońska, Z. Stosunki wodne w polskich Karpatach Zachodnich. Pr. Geogr. 1973, 103, 1-127.

40. Soja, R. Hydrologiczne Aspekty Antropopresji w Polskich Karpatach; IGiPZ PAN: Warszawa, Poland, 2002.

41. Timár, G.; Molnár, G.; Székely, B.; Biszak, S.; Varga, J.; Jankó, A. The Map Sheets of the Second Military Survey and Their Georeferenced Version; Arcanum: Budapest, Hungary, 2006; ISBN 963-7374-33-7.

42. Vichrova, M. Digital terrain model of the Second Military Survey. Two model territories: The surroundings of the town Rokycany and part of the military training area Brdy. E-Perimetron 2012, 7, 124-135. [CrossRef]

43. Kondracki, J. Geografia Polski. Mezoregiony Fizycznogeograficzne; Wyd. Nauk. PWN: Warszawa, Poland, 1994 ; ISBN 8301114223.

44. Oszczypko, N.; Ślączka, A.; Żytko, K. Regionalizacja tektoniczna Polski-Karpaty zewnętrzne i zapadlisko przedkarpackie. Przeglad Geol. 2008, 56, 927-935.

45. Polish Geological Institute Detailed Geological Map of Poland, 1:50,000. Available online: https://geologia.pgi.gov.pl/ (accessed on 10 October 2021).

46. Head Office of Geodesy and Cartography Map of Relief Shading, WMTS. Available online: https://mapy.geoportal.gov.pl/ (accessed on 25 October 2021).

47. National Water Management Board National Water and Environmental Programme. Available online: https://apgw.gov.pl/pl/ II-cykl-materialy-do-pobrania (accessed on 5 September 2021).

48. European Environment Agency European River Catchments. Available online: https://www.eea.europa.eu/data-and-maps/ data / european-river-catchments-1 (accessed on 5 September 2021).

49. Brice, J.C.; Blodgett, J.C. Counter Measures for Hydraulic Problems at Bridges. 1. Analysis and Assessment, Report No. FHWA-RD-78-162.; Federal Highway Administration: Washington, DC, USA, 1978.

50. Teisseyre, A.K. Klasyfikacja Rzek w świetle Analizy Systemu Fluwialnego i Geometrii Hydraulicznej; Wyd. Uniwersytetu Wrocławskiego: Wrocław, Poland, 1991.

51. Chełmicki, W.; Skapski, R.; Soja, R. Reżim hydrologiczny rzek karpackich w Polsce. Folia Geogr. Ser. Geogr. 1999, 29-30, 67-80.

52. Dynowska, I. Typy reżimów rzecznych w Polsce. Zesz. Nauk. UJ Pr. Geogr. 1971, 268, 1-147.

53. Wrzesiński, D.; Marsz, A.A.; Styszyńska, A.; Sobkowiak, L. Effect of the North Atlantic Thermohaline Circulation on changes in climatic conditions and river flow in Poland. Water 2019, 11, 1622. [CrossRef]

54. Fal, B. Zmienność odpływu z obszaru Polski w bieżącym stuleciu. Wiad. IMGW 1993, 16, 3-20.

55. Wrzesiński, D.; Sobkowiak, L. Detection of changes in flow regime of rivers in Poland. J. Hydrol. Hydromech. 2018, 66, 55-64. [CrossRef]

56. Broda, J. Proces wylesienia na ziemiach polskich od czasów najdawniejszych. Czas. Geogr. 1985, 56, 151-173.

57. Kozak, J.; Ziółkowska, E.; Vogt, P.; Dobosz, M.; Kaim, D.; Kolecka, N.; Ostafin, K. Forest-Cover Increase Does Not Trigger Forest-Fragmentation Decrease: Case Study from the Polish Carpathians. Sustainability 2018, 10, 1472. [CrossRef]

58. Kaim, D.; Kozak, J.; Kolecka, N.; Ziółkowska, E.; Ostafin, K.; Ostapowicz, K.; Gimmi, U.; Munteanu, C.; Radeloff, V.C. Broad scale forest cover reconstruction from historical topographic maps. Appl. Geogr. 2016, 67, 39-48. [CrossRef]

59. Bravard, J.-P.; Bethemont, J. Cartography of rivers in France. In Historical change of large alluvial rivers, Western Europe; Petts, G.E., Moller, H., Roux, A.L., Eds.; John Wiley \& Sons: Chichester, UK, 1989; pp. 95-111.

60. Hohensinner, S.; Jungwirth, M.; Muhar, S.; Schmutz, S. Spatio-temporal habitat dynamics in a changing Danube River landscape 1812-2006. River Res. Appl. 2011, 27, 939-955. [CrossRef] 
61. Carling, P.; Jansen, J.; Meshkova, L. Multichannel rivers: Their definition and classification. Earth Surf. Process. Landf. 2014, 39, 26-37. [CrossRef]

62. Nanson, G.C.; Knighton, D.A. Anabranching rivers: Their cause, character and classification. Earth Surf. Process. Landf. 1996, 21, 217-239. [CrossRef]

63. Rosgen, D.L. A Classification of Natural Rivers. Catena 1994, 22, 169-199. [CrossRef]

64. Kleinhans, M.G. Sorting out river channel patterns. Prog. Phys. Geogr. 2010, 34, 287-326. [CrossRef]

65. Schumm, S.A. Patterns of alluvial rivers. Annu. Rev. Earth Planet. Sci. 1985, 13, 5-27. [CrossRef]

66. Henriques, M.; McVicar, T.R.; Holland, K.L.; Daly, E. Riparian vegetation and geomorphological interactions in anabranching rivers: A global review. Ecohydrology 2021, e2370. [CrossRef]

67. Smith, D.G. Effect of vegetation on lateral migration of anastomosed channels of a glacial meltwater river. Geol. Soc. Am. Bull. 1976, 86, 857-860. [CrossRef]

68. Rzepecka, A.; Czajka, B.; Mikuś, P.; Kaczka, R.; Wyżga, B. Rozwój kępy o złożonej strukturze w żwirodennej rzece górskiej. Wyniki analiz dendrochronologicznych i kartograficznych. Stud. Mater. CEPL Rogowie 2012, 14, 105-110.

69. Winterbottom, S.J. Medium and short-term channel planform changes on the Rivers Tay and Tummel, Scotland. Geomorphology 2000, 34, 195-208. [CrossRef]

70. Szmańda, J.; Luc, M. Układ wielokorytowy Dunaju pomiędzy Ćunovem a Gabćikovem—Analiza przestrzenna na podstawie klasyfikacji rzek według Brice'a. Landf. Anal. 2010, 13, 129-133.

71. Ward, J.V.; Stanford, J.A. The serial discontinuity concept: Extending the model to floodplain rivers. Regul. Rivers Res. Manag. 1995, 10, 159-168. [CrossRef]

72. Church, M. Channel morphology and typology. In The Rivers Handbook; Calow, P., Petts, G.E., Eds.; Blackwell: Oxford, UK, 1992; pp. 126-143.

73. Notebaert, B.; Piégay, H. Multi-scale factors controlling the pattern of floodplain width at a network scale: The case of the Rhône basin, France. Geomorphology 2013, 200, 155-171. [CrossRef]

74. Poole, G.C. Fluvial landscape ecology: Addressing uniqueness within the river discontinuum. Freshw. Biol. 2002, 47, 641-660. [CrossRef]

75. Gorczyca, E. Myrphodynamics of the River Łososina channel after an Extreme Flood (Western Carpathian Mountains). Geografija 2007, 43, 70-77.

76. Korpak, J. The influence of river training on mountain channel changes (Polish Carpathian Mountains). Geomorphology 2007, 92, 166-181. [CrossRef]

77. Mueller, E.R.; Pitlick, J. Sediment supply and channel morphology in mountain river systems: 2 . Single thread to braided transitions. J. Geophys. Res. Earth Surf. 2014, 119, 1516-1541. [CrossRef]

78. Mueller, E.R.; Pitlick, J. Sediment supply and channel morphology in mountain river systems: 1. Relative importance of lithology, topography, and climate. J. Geophys. Res. Earth Surf. 2013, 118, 2325-2342. [CrossRef]

79. Ward, J.V.; Tockner, K.; Edwards, P.J.; Kollmann, J.; Bretschko, G.; Gurnell, A.M.; Petts, G.E.; Rossaro, B. A reference river system for the Alps: The 'Fiume Tagliamento'. Regul. Rivers Res. Manag. 1999, 15, 63-75. [CrossRef]

80. Zasadni, J.; Kłapyta, P. The Tatra Mountains during the Last Glacial Maximum. J. Maps 2014, 10, 440-456. [CrossRef]

81. Kłapyta, P. Geomorphology of the high-elevated flysch range-Mt. Babia Góra Massif (Western Carpathians). J. Maps 2020, 16, 689-701. [CrossRef]

82. Smith, N.D.; McCarthy, T.S.; Ellery, W.N.; Merry, C.L.; Rüther, H. Avulsion and anastomosis in the panhandle region of the Okavango Fan, Botswana. Geomorphology 1997, 20, 49-65. [CrossRef]

83. Schumm, S.A.; Khan, H.R. Experimental Study of Channel Patterns. GSA Bull. 1972, 83, 1755-1770. [CrossRef]

84. Leopold, L.B.; Wolman, M.G. River channel patterns-Braided, meandering and straight. US Geol. Surv. Prof. Pap. 1957, 282, 39-85.

85. Makaske, B. Anastomosing rivers. Forms, processes and sediments. Ned. Geogr. Stud. 1998, 249, 1-285.

86. Doeglas, D.J. Meandering and braided rivers. Geol. Mijnb. 1951, 13, 297-299.

87. Germanoski, D.; Schumm, S.A. Changes in Braided River Morphology Resulting from Aggradation and Degradation. J. Geol. 1993, 101, 451-466. [CrossRef]

88. Škarpich, V.; Hradecký, J.; Tábořík, P. Structure and genesis of the quaternary filling of the Slavíč River valley (Moravskoslezské Beskydy Mts., Czech Republic). Morav. Geogr. Rep. 2011, 19, 30-38.

89. Wojkowski, J.; Wałęga, A.; Radecki-Pawlik, A.; Młyński, D.; Lepeška, T. The influence of land cover changes on landscape hydric potential and river flows: Upper Vistula, Western Carpathians. CATENA 2021, 105878. [CrossRef]

90. Stacke, V.; Panek, T.; Sedlacek, J. Late Holocene evolution of the Bečva River floodplain (Outer Western Carpathians, Czech Republic) as a record of interaction between erosion-prone catchment and environmental change. Geomorphology 2014, 206, 440-451. [CrossRef]

91. Lach, J.; Wyżga, B. Channel incision and flow increase of the upper Wisłoka River, southern Poland, subsequent to the reforestation of its catchment. Earth Surf. Process. Landf. 2002, 27, 445-462. [CrossRef]

92. Perşoiu, I.; Rădoane, M. Spatial and temporal controls on historical channel responses—Study of an atypical case: Someşu Mic River, Romania. Earth Surf. Process. Landf. 2011, 36, 1391-1409. [CrossRef] 
93. Vandenberghe, J.; Woo, M. Modern and ancient periglacial river types. Prog. Phys. Geogr. Earth Environ. 2002, 26, 479-506. [CrossRef]

94. Kukulak, J. Impact of mediaeval agriculture on the alluvium in the San River headwaters (Polish Eastern Carpathians). CATENA 2003, 51, 255-266. [CrossRef]

95. Henkiel, A. Geomorphological microregions of the Polish Bieszczady Mountains. Ann. UMCS Sec. B 1997, 52, 133-145.

96. Scorpio, V.; Surian, N.; Cucato, M.; Dai Prá, E.; Zolezzi, G.; Comiti, F. Channel changes of the Adige River (Eastern Italian Alps) over the last 1000 years and identification of the historical fluvial corridor. J. Maps 2018, 14, 680-691. [CrossRef]

97. Bravard, J.-P. Discontinuities in braided patterns: The River Rhône from Geneva to the Camargue delta before river training. Geomorphology 2010, 117, 219-233. [CrossRef]

98. Van der Berg, J.H. Prediction of alluvial channel pattern of perennial rivers. Geomorphology 1995, 12, 259-279. [CrossRef]

99. Colombini, M.; Seminaria, G.; Tubino, M. Finite-amplitude alternate bars. J. Fluid Mech. 1987, 181, 213-232. [CrossRef]

100. Witkowski, K.; Witkowski, M. The impact of watermills on changes in the hydrographic network in the Carpathian Foothills in Poland. Carpathian J. Earth Environ. Sci. 2018, 13, 605-611. [CrossRef]

101. Kalicki, T.; Przepióra, P.; Kusztal, P.; Chrabąszcz, M.; Fularczyk, K.; Kłusakiewicz, E.; Frączek, M. Historical and present-day human impact on fluvial systems in the Old-Polish Industrial District (Poland). Geomorphology 2020, 357, 107062. [CrossRef]

102. Gorczyca, E.; Krzemień, K.; Jarzyna, K. The Evolution of Gravel-Bed Rivers during the Post-Regulation Period in the Polish Carpathians. Water 2020, 12, 254. [CrossRef]

103. Zawiejska, J.; Wyżga, B. Twentieth-century Channel Change on the Dunajec River, Southern Poland: Patterns, Causes and Controls. Geomorphology 2010, 117, 234-246. [CrossRef]

104. Klimek, K.; Trafas, K. Young-Holocene changes in the course of the Dunajec River in the Beskid Sadecki Mts (Western Carpathians). Stud. Geomorphol. Carpatho-Balc. 1972, 6, 85-92.

105. Zuchiewicz, W.; Tokarski, A.K.; Świerczewska, A.; Cuong, N.Q. Neotectonic activity of the Skawa River Fault Zone (Outer Carpathians, Poland). Ann. Soc. Geol. Pol. 2009, 79, 67-93.

106. Gorczyca, E. Rozwój Górskich Żwirodennych Koryt Rzecznych w Warunkach Antropopresji; Instytut Geografii i Gospodarki Przestrzennej UJ: Kraków, Poland, 2016; ISBN 9788364089251.

107. Sobucki, M.; Gorczyca, E.; Giriat, D. Human induced channel changes of the upper Wisłoka River during last 150 years (Polish Carpathian Mts.). In Proceedings of the FLAG Scientific Programme, Remich, Luxemburg, 2-7 September 2012 ; p. 28. 